\title{
Application of whole genome re- sequencing data in the development of diagnostic DNA markers tightly linked to a disease-resistance locus for marker-assisted selection in lupin (Lupinus angustifolius)
}

Huaan Yang ${ }^{1 \dagger}$, Jianbo Jian ${ }^{2 \dagger}, X^{\prime}$ uan $\mathrm{Li}^{2}$, Daniel Renshaw ${ }^{1}$, Jonathan Clements ${ }^{1}$, Mark W. Sweetingham', Cong $\operatorname{Tan}^{3}$ and Chengdao $\mathrm{Li}^{1,3^{*}}$

\begin{abstract}
Background: Molecular marker-assisted breeding provides an efficient tool to develop improved crop varieties. A major challenge for the broad application of markers in marker-assisted selection is that the marker phenotypes must match plant phenotypes in a wide range of breeding germplasm. In this study, we used the legume crop species Lupinus angustifolius (lupin) to demonstrate the utility of whole genome sequencing and re-sequencing on the development of diagnostic markers for molecular plant breeding.

Results: Nine lupin cultivars released in Australia from 1973 to 2007 were subjected to whole genome re-sequencing. The re-sequencing data together with the reference genome sequence data were used in marker development, which revealed 180,596 to 795,735 SNP markers from pairwise comparisons among the cultivars. A total of 207,887 markers were anchored on the lupin genetic linkage map. Marker mining obtained an average of 387 SNP markers and 87 InDel markers for each of the 24 genome sequence assembly scaffolds bearing markers linked to 11 genes of agronomic interest. Using the R gene PhtjR conferring resistance to phomopsis stem blight disease as a test case, we discovered 17 candidate diagnostic markers by genotyping and selecting markers on a genetic linkage map. A further 243 candidate diagnostic markers were discovered by marker mining on a scaffold bearing non-diagnostic markers linked to the PhtiR gene. Nine out from the ten tested candidate diagnostic markers were confirmed as truly diagnostic on a broad range of commercial cultivars. Markers developed using these strategies meet the requirements for broad application in molecular plant breeding.
\end{abstract}

Conclusions: We demonstrated that low-cost genome sequencing and re-sequencing data were sufficient and very effective in the development of diagnostic markers for marker-assisted selection. The strategies used in this study may be applied to any trait or plant species. Whole genome sequencing and re-sequencing provides a powerful tool to overcome current limitations in molecular plant breeding, which will enable plant breeders to precisely pyramid favourable genes to develop super crop varieties to meet future food demands.

Keywords: Genome sequencing, Re-sequencing, Next-generation sequencing (NGS), Marker-assisted selection (MAS), Diagnostic markers, Precision breeding

\footnotetext{
* Correspondence: chengdao.li@agric.wa.gov.au

${ }^{\dagger}$ Equal contributors

'Department of Agriculture and Food Western Australia, 3 Baron-Hay Court,

South Perth 6151, Australia

${ }^{3}$ State Agricultural Biotechnology Centre, Murdoch University, Murdoch 6150,

Australia

Full list of author information is available at the end of the article
} 


\section{Background}

Over thousands of years, the success of plant breeding and selection has relied on phenotypic measurements and breeder experience. The Green Revolution has greatly boosted the world grain production from the 1940s to 1960s. The advent of molecular biotechnology has progressively provided improved tools for precision plant breeding for genetic improvement. The concept of marker-assisted selection (MAS) in plant breeding was proposed in the 1980s [1], and has the potential to vastly enhance the efficiency of genetic improvement $[2,3]$. In the last 30 years, molecular markers have been gradually applied to assist plant breeding of agricultural crops. A small number of commercial varieties obtained through marker-assisted breeding were released in rice, soybean, maize, barley, wheat and potato [3]. However, the gap between the expectations and actual impact of MAS is well recognised. Most of the thousands of publications with the terms "markerassisted selection", "quantitative trait loci (QTLs)" or "molecular markers" have failed to show any impact in plant breeding [3-5].

There are two major challenges in developing molecular markers for MAS. Firstly, markers must be closely linked to genes of agronomic traits of interest to enable the accurate prediction of desired plant phenotypes [3]. The most desirable markers for MAS are "co-segregating", where marker genotypes are completely consistent with plant phenotypes in segregating breeding populations. Cosegregating markers offer maximum accuracy on MAS $[6,7]$. Secondly, the genotypes of the markers should match plant phenotypes in a wide range of breeding germplasm, allowing broad application in a breeding program. Unfortunately, most of the molecular markers developed over the last 30 years through DNA fingerprinting and genetic mapping are not on target gene sequences; and some genetic distances exist between markers and genes. As a result, genetic recombination may occur in the region between the marker and the gene on the chromosome during evolution and in the plant breeding process. In MAS practice, it is a common problem that cultivars exhibiting desirable marker genotypes may not necessarily have the targeted genes and vice versa, which is known as "false positives" $[8,9]$. When a cultivar containing a desirable gene is crossed with a breeding line with a false positive marker genotype, the $F_{2}$ progeny plants will show the same marker allele, even though the gene of interest is segregating; therefore, the marker cannot be used for MAS. In order to deal with the prevalence of the false positives, molecular biologists have to undertake "marker validation" work to determine which markers fit which crosses in plant breeding programs $[8,9]$. The marker validation step not only increases the overall cost, but also greatly slows down the pace of MAS [8-11]. The best solution for this plight is to develop "diagnostic markers" [12]; that is, markers which have marker genotypes consistent with plant trait phenotypes in all of the breeding germplasm in a breeding program. Diagnostic markers can be used in MAS without the marker validation step [12]. It is now well recognised that the development of diagnostic markers is the key for successful, large-scale and broad application of MAS in plant breeding [10-12].

Functional markers designed on target gene sequences are diagnostic [12], but their development requires identifying, cloning and understanding the genes and their functions. Non-genic diagnostic markers can be developed on random sequences without knowledge of the causal genes by DNA fingerprinting and genetic mapping to select markers with genotypes matched to plant phenotypes in breeding germplasm [13-15]. Traditional methods of developing functional markers and diagnostic markers are tedious and time consuming [16]. The advancements in next-generation sequencing (NGS) and whole genome sequencing have vastly improved the capacity for marker discovery in plants. For example, more than 55 million SNPs were discovered in maize by genome sequencing and re-sequencing $[17,18]$ and 18.9 million SNPs were obtained by re-sequencing a core collection of rice accessions [19]. Although genome sequencing has been increasingly applied to a wide range of plant species in recent years, there is no report on how to use whole genome sequencing and re-sequencing data to overcome the key challenges and to develop markers widely applicable for plant breeding programs.

Narrow-leafed lupin (Lupinus angustifolius L.) was fully domesticated by the early 1970s in Australia and is currently cultivated in Australia, Europe, America and Africa. Over the last 15 years, the DNA fingerprinting method microsatellite-anchored fragment length polymorphism (MFLP) [20] has been used to develop PCR-based markers linked to major genes of industry importance in lupin [16, 21-30]. A genetic linkage map was published in 2005 based on a $\mathrm{F}_{8}$ recombinant inbred line (RIL) population originating from a wild $\times$ domesticated cross [31]. Three updated versions of the map from the same mapping population followed [32-34]. Most of the markers on these maps were anonymous without sequence information. The application of NGS technology in the last four years has accelerated molecular research on this legume species. NGS has been used to end-sequence a small portion of a bacterial artificial chromosome (BAC) library [35] and in a transcriptome study [36]. NGS was applied as a DNA fingerprinting method to rapidly develop markers for MAS [37], and to construct a sequence-defined, dense genetic map in lupin [38]. More significantly, a draft genome sequence has been established, providing first insight into the lupin genome [38]. 
Phomopsis stem blight (PSB) caused by the fungal pathogen Diaporthe toxica is a major disease in lupin. It infects young stems, remaining as a latent subcuticular coralloid hyphal structure in green plants [39]. Upon plant senescence, the fungus colonizes the stems and develops large lesions. During saprophytic colonization, the fungus produces mycotoxins which can kill animals that graze on lupin stubble [40]. Selection for PSB disease resistance is a key objective in lupin breeding programs. Conventional methods of screening for PSB resistance are difficult and time consuming [41, 42]. Genetic analysis has indicated at least three major genes (Phrl, Phrl and PhtjR) among Australian domesticated lupin lines, each independently conferring resistance to PSB $[43,44]$. The R gene PhtjR is present in cultivar Tanjil, which has been extensively used as a parental line in the Australian lupin breeding program since its release in 1998. Seven sequence-specific, simple PCR-based markers were developed which flank the R gene PhtjR [44]; unfortunately, none have both the key characters of co-segregating and diagnostic desired for MAS. The R gene PhtjR has been integrated in the dense genetic map [38]. The objectives of this study were: (1) to undertake genome sequencing and re-sequencing on representative commercial lupin cultivars to discover molecular markers at the whole genome level, and (2) to examine the use of whole genome sequencing and re-sequencing to rapidly develop diagnostic markers closely linked to genes of agronomic interest for large scale application of MAS in molecular lupin breeding without the knowledge of functional genes.

\section{Results}

\section{Whole genome re-sequencing in nine cultivars}

The sequenced commercial cultivars were selected to represent a subset of the lupin breeding history released from 1973 to 2007. For each of the nine re-sequenced lupin cultivars, approximately 10 to $16 \mathrm{~Gb}$ of high quality clean sequencing data was obtained (Table 1), which represents 9-15X coverage of the lupin genome size at $1.1 \mathrm{~Gb}$ [38].
The sequence reads for each cultivar were assembled into scaffolds using the software program SOAPdenovo [45], and the N50 of assembled scaffolds for each cultivar ranged from 7,633 bp to 10,864 bp (Table 1). The total length of scaffold span for each cultivar ranged from $485 \mathrm{Mbp}$ to 513 Mbp, approximately $90 \%$ of the length of the reference genome assembly based on cultivar Tanjil [38]. The genome GC content of all re-sequenced cultivars was around $32 \%$ (Table 1), which was consistent with the GC content of the reference genome [38].. The re-sequencing data of the nine lupin cultivars have been deposited at Genbank (NCBI accession number: "PRJNA290411"; website address: http:// www.ncbi.nlm.nih.gov/bioproject/PRJNA290411).

\section{Marker discovery by genome sequencing and re- sequencing}

Pairwise comparison of whole genome sequencing data among the reference genome (cultivar Tanjil) and nine re-sequenced lupin cultivars revealed 180,596-795,735 SNP markers (Table 2). The number of insertion/deletion (InDel) markers between cultivars ranged from 33,094 to 122,513 . In general, the number of InDels was positively correlated with the number of SNPs detected for each cultivar (Table 2).

Sequence comparison between the reference genome sequence cultivar Tanjil and each of the nine re-sequenced cultivars revealed significant genetic diversity variation at the genome level and at chromosome level (Fig. 1). Cultivar Unicrop, which was the earliest fully domesticated cultivar in this species with most distant pedigree kinship from later released cultivars, showed the greatest level of diversity. In comparison, cultivar Merrit, which has the closest pedigree kinship which reference genome cultivar Tanjil [46], exhibited the least diversity among the nine sequenced cultivars (Fig. 1). At chromosome level, the sequences in sequencedefined linkage group [38] SLG-1, SLG-2, SLG-8 and SLG11 were highly diverse; while SLG-3 was more conserved, particularly in the second half of this linkage group (Fig. 1).

Table 1 Statistics of denovo genome sequence assembly of re-sequenced nine cultivars of Lupinus angustifolius

\begin{tabular}{llllllllll}
\hline & Unicrop & Yorrel & Merrit & Kalya & Tallerack & Quilinock & Mandelup & Coromup & Jenabilup \\
\hline Raw data (Mbp) & 13,334 & 14,322 & 15,958 & 15,760 & 11,043 & 17,275 & 17,727 & 15,242 & 14,588 \\
Clean data (Mbp) & 12,714 & 13,642 & 15,275 & 15,069 & 10,524 & 16,471 & 16,936 & 14,605 & 14,003 \\
Q20 base rate (\%) & 95.3 & 96.6 & 96.9 & 97.0 & 95.9 & 96.8 & 97.0 & 97.0 & 97.1 \\
Number of scaffolds & 208,181 & 277,622 & 309,904 & 371,733 & 256,387 & 279,705 & 383,911 & 268,036 & 363,979 \\
Total scaffold span (Mbp) & 485 & 497 & 501 & 513 & 488 & 500 & 512 & 504 & 498 \\
Scaffold N50 (bp) & 10,864 & 9,463 & 8,814 & 9,307 & 9,070 & 9,835 & 9,423 & 10,487 & 7,633 \\
Average scaffold length (bp) & 2,332 & 1,789 & 1,617 & 1,380 & 1,905 & 1,789 & 1,332 & 1,882 & 1,369 \\
Longest scaffold (bp) & 305,995 & 183,544 & 191,423 & 156,385 & 229,074 & 228,256 & 147,382 & 211,945 & 125,123 \\
GC content (\%) & 32.96 & 32.70 & 32.87 & 32.87 & 32.62 & 32.72 & 32.90 & 32.65 & 32.89 \\
\hline
\end{tabular}


Table 2 Numbers of SNP markers and InDel markers discovered by pairwise comparison of whole genome sequencing and re-sequencing data among 10 cultivars of Lupinus angustifolius*

\begin{tabular}{|c|c|c|c|c|c|c|c|c|c|c|}
\hline Lupin cultivars & & Unicrop & Yorrel & Merrit & Kalya & Tallerack & Quilinock & Mandelup & Coromup & Jenabillup \\
\hline \multirow[t]{2}{*}{ Yorrel } & SNP & 361,783 & & & & & & & & \\
\hline & InDel & 74,074 & & & & & & & & \\
\hline \multirow[t]{2}{*}{ Merrit } & SNP & 387,619 & 379,884 & & & & & & & \\
\hline & InDel & 42,670 & 53,825 & & & & & & & \\
\hline \multirow[t]{2}{*}{ Kalya } & SNP & 231,674 & 363,644 & 399,442 & & & & & & \\
\hline & InDel & 50,771 & 70,606 & 40,572 & & & & & & \\
\hline \multirow[t]{2}{*}{ Tallerack } & SNP & 457,861 & 516,424 & 581,288 & 466,314 & & & & & \\
\hline & InDel & 84,239 & 100,668 & 71,220 & 80,863 & & & & & \\
\hline \multirow[t]{2}{*}{ Quilinock } & SNP & 358,425 & 402,839 & 386,350 & 370,174 & 521,485 & & & & \\
\hline & InDel & 60,592 & 74,470 & 39,501 & 56,952 & 86,272 & & & & \\
\hline \multirow[t]{2}{*}{ Mandelup } & SNP & 383,509 & 333,375 & 363,518 & 405,193 & 525,458 & 399,216 & & & \\
\hline & InDel & 59,611 & 62,906 & 34,838 & 57,048 & 83,158 & 57,406 & & & \\
\hline \multirow[t]{2}{*}{ Coromup } & SNP & 358,729 & 318,466 & 338,840 & 377,613 & 509,809 & 365,480 & 210,394 & & \\
\hline & InDel & 59,469 & 61,381 & 35,666 & 57,069 & 84,167 & 55,839 & 39,077 & & \\
\hline \multirow[t]{2}{*}{ Jenabillup } & SNP & 325,324 & 360,401 & 312,064 & 330,028 & 452,170 & 180,596 & 287,423 & 266,773 & \\
\hline & InDel & 52,035 & 65,258 & 27,406 & 48,075 & 75,939 & 33,094 & 42,073 & 41,398 & \\
\hline \multirow[t]{2}{*}{ Tanjil (Reference) } & SNP & 644,901 & 510,722 & 432,717 & 564,221 & 795,735 & 609,359 & 601,497 & 543,048 & 467,465 \\
\hline & InDel & 93,730 & 105,235 & 59,780 & 90,986 & 122,513 & 93,675 & 88,261 & 88,910 & 79,623 \\
\hline
\end{tabular}

* SNP markers are presented in black; InDel markers are in green

\section{Genotyping sequence-defined DNA markers on a genetic linkage map}

The genome sequencing and re-sequencing data were successfully applied to genotype markers in the sequencedefined lupin genetic linkage map [38]. A total of 3,277 DNA markers from the 20 linkage groups were characterized for the 10 sequenced cultivars, including 2,902 SNP markers and 375 InDel markers (Additional file 1). By using the DNA sequences bearing the marker variation sites to Blast search of the genome sequencing data, the genotypes of these 3,277 markers on the reference cultivars Tanjil and on the nine re-sequenced cultivars were obtained and recorded (Additional file 1). For completeness, Additional file 1 contains all the 20 SLGs, the list of mapped SNP markers and InDel markers, the sequences bearing the marker sites, and the positions of nucleotides of the mapped markers in their corresponding scaffolds in the reference genome sequence assembly [38].

Enrichment of molecular markers for the lupin genetic map Sequence alignments on the 4,214 scaffolds anchored on the sequence-defined lupin genetic linkage map between the two cultivars Tanjil and Unicrop, the two parental lines of the $F_{8}$ RIL mapping population used to establish the dense genetic linkage map [38], identified 207,887 markers, which included 174,639 SNP markers and 33,248 InDel markers (Additional file 2). The average marker density of the enriched genetic linkage map was 127 markers per
CentiMorgan. The distribution of these markers in each linkage group is summarized in Table 3 . The average length of the 4,214 scaffolds anchored on the genetic linkage map was 17,035 bp. The average numbers of SNP markers and InDel markers per scaffold were 41.4 and 7.9 , respectively. Detailed numbers of markers detected on each anchored scaffold, and their corresponding positions in the genetic linkage map are presented in Additional file 2.

\section{Marker mining on scaffolds linked to genes of agronomic traits of interest}

The 24 previously-developed DNA markers linked to 11 genes of agronomic traits of interest were located on 23 scaffolds in the draft genome sequence assembly [38]. Marker MoA [23] and MoLI [30] were on the same scaffold. Each of the other 22 markers was on a separate specific scaffold (Table 4). The length of these 23 scaffolds ranged from 8,191 bp to $64,039 \mathrm{bp}$, and the average length was 27,687 bp (Table 4).

Sequence alignments on the 23 scaffolds among 10 sequenced cultivars discovered a total of 8,700 SNP markers and 1,997 InDel markers (Table 4). The average numbers of SNP and InDel markers for each scaffold were 378 and 87, respectively. Generally, scaffolds in longer length contained more markers than shorter scaffolds. For example, scaffold2572 (55,753 bp in length) contained 1,071 markers; while scaffold36247 (8,191 bp in length) had 66 markers (Table 4). 


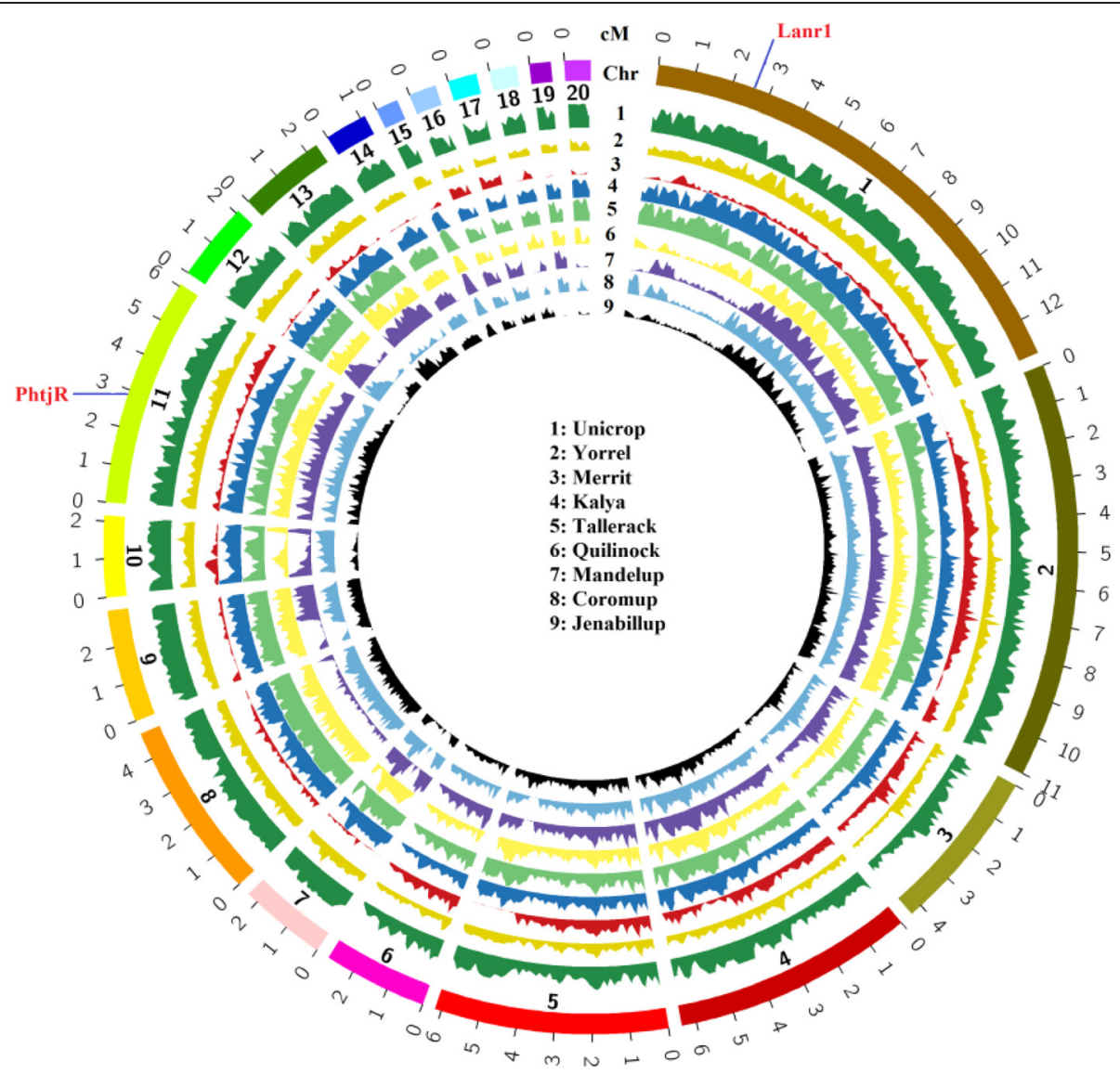

Fig. 1 Genome-wide genetic diversity as measured by SNP abundance along each linkage group between reference cultivar Tanjil and nine re-sequenced cultivars of Lupinus angustifolius. Twenty linkage groups (SLG) were displayed in a circle. The inner number was SLG index and the outer was physical position (Mb). The circular histograms from circular 1 to 9 with different filling colour were SNP frequency distributions of nine cultivars in whole genome and the response relationship was given in the core area. Higher peaks indicated larger number of SNPs in the interval and lower troughs meant low abundance of SNP. The SNP frequency was counted in non-overlapping 100 $\mathrm{kb}$ intervals along each chromosome

Development of diagnostic markers linked to the $\mathrm{R}$ gene PhtjR by genotyping markers from the genetic linkage map

The R gene PhtjR conferring resistance to PSB disease was mapped in the SLG-11 of the sequence-defined genetic linkage map of lupin (Additional file 1). Of the 3,277 genotyped markers, 343 were on SLG-11 (Additional file 1). Thirty-three genotyped markers were distributed within 5 centiMorgans (cM) of the $\mathrm{R}$ gene PhtjR (highlighted in green in Additional file 1; also presented in Table 5). The comparison between the $P h t j R$ gene phenotypes and the marker genotypes among the 10 sequenced cultivars identified 17 markers where the marker genotypes completely matched the PSB disease phenotypes (Table 5); these 17 markers were considered "candidate diagnostic markers" for the PhtjR gene. The other 18 markers showed the R-allele marker genotype on one or more cultivars without the $\mathrm{R}$ gene, which is the linkage disequilibrium decay [47], and is also called "false positive" [11, 48, 49] (Table 5).

Five candidate diagnostic markers, together with five non-diagnostic markers as controls, were converted into sequence-specific simple PCR markers by designing a pair of sequence-specific primers flanking each SNP site (Table 6). Validation tests confirmed that the five candidate diagnostic markers, DAFWA926, DAFWA2836, DAFWA3 794, DAFWA6277 and DAFWA8077, were truly diagnostic on the 27 historical and current commercial cultivars released in Australia (Table 7). The three SNP markers most closely linked to the R gene (co-segregating), DAFWA3123, DAFWA4020 and DAFWA6895, had six to eight false positives (Table 7). SNP markers DAFWA2747 and DAFWA4021 have seven and eight false positives, respectively (Table 7). The genotypes of SNP markers were easily differentiated by high resolution melting (HRM) on LightScanner (Fig. 2). 
Table 3 Summary of SNP markers and InDel markers integrated into the sequence-defined genetic linkage map through sequence comparison on scaffolds in Lupinus angustifolius ${ }^{a}$

\begin{tabular}{|c|c|c|c|c|}
\hline Linkage groups & Genetic length (cM) & Number of anchored scaffolds ${ }^{b}$ & Number of SNP markers detected & Number of InDel markers detected \\
\hline$\overline{\mathrm{SLG}-1}$ & 234.3 & 763 & 35,605 & 5,036 \\
\hline SLG-2 & 156.7 & 724 & 24,158 & 5,190 \\
\hline SLG-3 & 149 & 236 & 8,071 & 2,027 \\
\hline SLG-4 & 144.2 & 400 & 14,160 & 3,202 \\
\hline SLG-5 & 101.9 & 365 & 13,028 & 2,654 \\
\hline SLG-6 & 89 & 129 & 4,830 & 1,437 \\
\hline SLG-7 & 86.5 & 114 & 6,959 & 1,512 \\
\hline SLG-8 & 85 & 289 & 13,761 & 1,688 \\
\hline SLG-9 & 83.5 & 155 & 8,772 & 1,578 \\
\hline SLG-10 & 82.6 & 138 & 6,230 & 1,132 \\
\hline SLG-11 & 82.2 & 344 & 13,869 & 2,164 \\
\hline SLG-12 & 64.9 & 143 & 5,778 & 1,094 \\
\hline SLG-13 & 52.2 & 155 & 6,566 & 1,022 \\
\hline SLG-14 & 51.1 & 57 & 2,806 & 735 \\
\hline SLG-15 & 34.5 & 32 & 1,676 & 430 \\
\hline SLG-16 & 33.3 & 47 & 1,468 & 443 \\
\hline SLG-17 & 32.4 & 40 & 1,612 & 549 \\
\hline SLG-18 & 26.6 & 28 & 1,616 & 478 \\
\hline SLG-19 & 20.6 & 13 & 1,499 & 416 \\
\hline SLG-20 & 19.4 & 42 & 2,175 & 461 \\
\hline Sub total & 1629.9 & 4,214 & 174,639 & 33,248 \\
\hline
\end{tabular}

${ }^{\mathrm{a}}$ The sequence-defined genetic linkage map has been published previously [38]

${ }^{\mathrm{b}}$ Full list of scaffolds anchored on the genetic linkage map, and the number of markers detected from each scaffold are presented in Additional file 2

Development of diagnostic markers linked to the $\mathrm{R}$ gene PhtjR by marker mining on a genome sequence assembly scaffold

The three SNP markers most-tightly linked to the R gene PhtjR (co-segregating, genetic distance $0 \mathrm{cM}$ ) on the genetic linkage map were DAFWA3132, DAFWA4020 and DAF WA6895 (Additional file 1), which were confirmed as nondiagnostic (Table 7). These three SNP markers on the same scaffold 84773 in the lupin genome sequence assembly (Additional file 1). Scaffold84773 was used as a test case to investigate the feasibility of developing diagnostic markers by marker mining on genome sequencing assembly scaffolds.

The length of scaffold 84773 on the reference genome sequence assembly based on cultivar Tanjil (Genbank accession number "gi 448398638", AOCW01145302) was 33,448 bp. DNA sequence alignment of the 10 sequenced cultivars on scaffold84773 revealed 489 SNP markers and 101 InDel markers (Additional file 3). Of the 489 SNP markers, 187 had marker genotypes completely matching with $P h t j R$ gene phenotypes on all 10 lupin cultivars, and were considered candidate diagnostic markers (highlighted in green in Additional file 3). The other
302 SNP markers were non-diagnostic, evidenced by one or more false positives in the 10 sequenced cultivars. Similarly, 56 InDel markers were identified as candidate diagnostic markers (highlighted in blue in Additional file 3); the other 45 InDel markers were non-diagnostic (Additional file 3).

A small subset of 10 SNP markers and four InDel markers arising from sequence alignment on scaffold 84773 were selected for further investigation (Table 8). These 14 markers exhibited a wide range of variation in marker genotypes among 10 sequenced lupin cultivars. Markers SNP20, SNP25, SNP263, SNP271, InDel2 and InDel10 showed marker genotypes consistent with $\mathrm{R}$ gene PhtjR phenotypes of all 10 sequenced cultivars, and were identified as candidate diagnostic markers. On the 10 sequenced cultivars, false positives were discovered in InDel28 (1), SNP250, SNP268 and InDel66 (2), SNP264 (7), and SNP 267 and SNP272 (8) (Table 8). Six SNP markers and four InDel markers were converted to sequence-specific PCR markers by designing a pair of sequence-specific primers flanking the marker variation sites (Table 9). Validation tests on the 27 Australian historical and commercial cultivars confirmed three SNP markers, SNP20, SNP25 and 
Table 4 Marker mining on 23 genome sequence assembly scaffolds bearing 24 markers linked to 11 key genes of agronomic traits of interest by sequence alignments among 10 sequenced cultivars of Lupinus angustifolius ${ }^{a}$

\begin{tabular}{|c|c|c|c|c|c|c|c|}
\hline Agronomic traits & $\begin{array}{l}\text { Name of } \\
\text { markers }\end{array}$ & $\begin{array}{l}\text { Distance between } \\
\text { marker and target } \\
\text { gene }(\mathrm{cM})\end{array}$ & Reference & $\begin{array}{l}\text { Scaffold } \\
\text { identified }\end{array}$ & $\begin{array}{l}\text { Scaffold } \\
\text { size (bp) }\end{array}$ & $\begin{array}{l}\text { Number of SNP markers } \\
\text { from scaffold sequence } \\
\text { alignment }\end{array}$ & $\begin{array}{l}\text { Number of InDel markers } \\
\text { from scaffold sequence } \\
\text { alignment }\end{array}$ \\
\hline $\begin{array}{l}\text { Disease resistance } \\
\text { gene PhtjR }\end{array}$ & DAFWA6895 & 0 & [38] & Scaffold84773 & 33,448 & 489 & 101 \\
\hline $\begin{array}{l}\text { Disease resistance } \\
\text { gene PhtjR }\end{array}$ & PhtjM1 & 1.3 & [44] & scaffold70674 & 11,068 & 102 & 39 \\
\hline $\begin{array}{l}\text { Disease resistance } \\
\text { gene PhtjR }\end{array}$ & PhtjM4 & 1.1 & [44] & scaffold16849 & 40,716 & 526 & 259 \\
\hline $\begin{array}{l}\text { Disease resistance } \\
\text { gene PhtjR }\end{array}$ & PhtjM6 & 1.9 & [44] & scaffold2572 & 55,753 & 808 & 263 \\
\hline $\begin{array}{l}\text { Disease resistance } \\
\text { gene PhtjR }\end{array}$ & PhtjM7 & 1.1 & [44] & scaffold57606 & 13,893 & 188 & 62 \\
\hline $\begin{array}{l}\text { Disease resistance } \\
\text { gene Lanr1 }\end{array}$ & DAFWA5820 & 0 & {$[38]$} & $\begin{array}{l}\text { scaffold } \\
31581\end{array}$ & 15,706 & 225 & 33 \\
\hline $\begin{array}{l}\text { Disease resistance } \\
\text { gene Lanr1 }\end{array}$ & AntjM1 & 3.5 & {$[22]$} & scaffold83350 & 11,407 & 74 & 35 \\
\hline $\begin{array}{l}\text { Disease resistance } \\
\text { gene Lanr } 1\end{array}$ & AntjM2 & 2.3 & [14] & scaffold2992 & 33,979 & 341 & 188 \\
\hline $\begin{array}{l}\text { Disease resistance } \\
\text { gene Lanr } 1\end{array}$ & AnSeq3 & 0.9 & {$[37]$} & Scaffold33942 & 64,039 & 716 & 138 \\
\hline $\begin{array}{l}\text { Disease resistance } \\
\text { gene Lanr1 }\end{array}$ & AnSeq4 & 0.9 & {$[37]$} & Scaffold31346 & 33,727 & 221 & 158 \\
\hline Seed coat colour & DAFWA6428 & 0 & [38] & scaffold11676 & 22,481 & 588 & 154 \\
\hline Seed coat colour & DAFWA4544 & 0 & {$[38]$} & scaffold13708 & 44,176 & 821 & 81 \\
\hline $\begin{array}{l}\text { Disease resistance } \\
\text { gene AnMan }\end{array}$ & AnManM1 & 5.0 & {$[16]$} & scaffold36514 & 50,220 & 311 & 213 \\
\hline $\begin{array}{l}\text { Disease resistance } \\
\text { gene Phr } 1\end{array}$ & $\mathrm{Ph} 258 \mathrm{M} 1$ & 5.7 & [21] & scaffold84752 & 21,471 & 292 & 94 \\
\hline $\begin{array}{l}\text { Disease resistance } \\
\text { gene Phr } 1\end{array}$ & Ph258M2 & 2.1 & [21] & scaffold 16252 & 15,559 & 212 & 25 \\
\hline $\begin{array}{l}\text { Resistance gene } \\
\text { against lupin rust } \\
\text { disease }\end{array}$ & RustM1 & Unknown & Unpublished & scaffold15347 & 42,210 & 578 & 25 \\
\hline $\begin{array}{l}\text { Early flowering } \\
\text { gene } K u\end{array}$ & $\mathrm{KuH}$ & 0 & {$[25]$} & scaffold21489 & 30,923 & 676 & 23 \\
\hline $\begin{array}{l}\text { Soft-seed coat } \\
\text { gene mollis }\end{array}$ & MoA, MoLi & 0 & {$[23,30]$} & scaffold75616 & 14,783 & 63 & 16 \\
\hline $\begin{array}{l}\text { Pod-non- } \\
\text { shattering le }\end{array}$ & LeLi & 6.0 & {$[29]$} & scaffold87978 & 9,909 & 59 & 17 \\
\hline $\begin{array}{l}\text { Pod-non- } \\
\text { shattering gene le }\end{array}$ & LeM2 & 1.3 & [24] & scaffold79908 & 20,738 & 103 & 22 \\
\hline $\begin{array}{l}\text { Pod-non- } \\
\text { shattering gene } \\
\text { tardus }\end{array}$ & TaM1 & 2.1 & [26] & scaffold15347 & 21,529 & 578 & 25 \\
\hline $\begin{array}{l}\text { Pod-non- } \\
\text { shattering gene } \\
\text { tardus }\end{array}$ & TaLi & 1.4 & [27] & scaffold36274 & 8,191 & 62 & 4 \\
\hline $\begin{array}{l}\text { Low alkaloid } \\
\text { gene iucundus }\end{array}$ & lucLi & 0.9 & {$[28]$} & scaffold30160 & 20,677 & 667 & 22 \\
\hline \multicolumn{5}{|c|}{ Average scaffold size and marker numbers } & 27,687 & 378 & 87 \\
\hline
\end{tabular}

${ }^{a}$ The list of 10 sequenced cultivars is presented in Tables 2 and 5 
Table 5 Identification of candidate diagnostic markers through genotyping sequence-defined markers with whole genome sequencing data from 10 cultivars on genetic linkage map flanking the $\mathrm{R}$ gene PhtjR conferring resistance to phomopsis in Lupinus angustifolius

\begin{tabular}{|c|c|c|c|c|c|c|c|c|c|c|c|c|c|c|}
\hline $\begin{array}{l}\text { Name of } \\
\text { markers }^{\mathrm{a}}\end{array}$ & $\begin{array}{c}\text { Distance to } R \\
\text { gene }(\mathrm{cM})\end{array}$ & $\begin{array}{l}\begin{array}{l}\text { Marker } \\
\text { variation }\end{array} \\
\end{array}$ & $\begin{array}{l}\text { Marker position on } \\
\text { reference scaffolds }^{\mathrm{c}}\end{array}$ & Tanjil & Unicrop & Yorrel & Merrit & Kalya & Tallerack & Quilinock & Mandelup & Coromup & Jenabillup & $\begin{array}{l}\text { Number of "false } \\
\text { positives"d }\end{array}$ \\
\hline DAFWA2895 & 5.1 & {$[\mathrm{C} / \mathrm{T}]$} & scaffold69396:826 & $T$ & $\mathrm{C}$ & $\because$ & $\mathrm{C}$ & $\mathrm{C}$ & - & $\mathrm{C}$ & $\mathrm{C}$ & $\mathrm{C}$ & $\mathrm{C}$ & 0 \\
\hline DAFWA926 & 5.1 & {$[\mathrm{G} / \mathrm{A}]$} & scaffold69396:729 & A & $\mathrm{G}$ & G & G & G & - & G & G & G & $\mathrm{G}$ & 0 \\
\hline DAFWA2836 & 5.1 & {$[\mathrm{~T} / \mathrm{C}]$} & scaffold $6420: 4269$ & C & $\mathrm{T}$ & $\mathrm{T}$ & $\mathrm{T}$ & $\mathrm{T}$ & - & $\mathrm{T}$ & - & $\mathrm{T}$ & $\mathrm{T}$ & 0 \\
\hline DAFWA3762 & 5.1 & {$[\mathrm{~A} / \mathrm{T}]$} & scaffold84623:913 & $\mathrm{T}$ & A & A & A & A & A & A & A & & A & 0 \\
\hline iDAFWA657 & 5.1 & {$[\mathrm{G}]$} & scaffold64552:1467 & ins & del & del & del & del & del & del & del & del & del & 0 \\
\hline DAFWA7356 & 4.3 & {$[\mathrm{C} / \mathrm{T}]$} & scaffold98285:10243 & $\mathrm{T}$ & $\mathrm{C}$ & $\mathrm{T}^{\mathrm{d}}$ & $\mathrm{C}$ & $\mathrm{C}$ & - & $\mathrm{C}$ & $\mathrm{C}$ & - & $\mathrm{C}$ & 1 \\
\hline DAFWA8362 & 4.3 & {$[\mathrm{G} / \mathrm{A}]$} & scaffold98285:5383 & A & G & A & G & $\mathrm{G}$ & - & $\mathrm{G}$ & G & G & - & 1 \\
\hline DAFWA7910 & 4.3 & {$[\mathrm{C} / \mathrm{G}]$} & scaffold98285:5622 & G & C & C & C & C & - & C & C & C & - & 0 \\
\hline DAFWA7481 & 2.1 & {$[\mathrm{G} / \mathrm{A}]$} & scaffold2572:46673 & A & G & A & - & G & G & G & - & G & G & 1 \\
\hline DAFWA3794 & 2.1 & {$[\mathrm{C} / \mathrm{T}]$} & scaffold2572:39132 & $\mathrm{T}$ & C & C & C & C & C & C & C & C & - & 0 \\
\hline DAFWA2747 & 2.1 & {$[\mathrm{~A} / \mathrm{G}]$} & scaffold17652:1131 & G & A & G & G & A & A & A & A & A & A & 2 \\
\hline DAFWA6409 & 2.1 & {$[\mathrm{~T} / \mathrm{C}]$} & scaffold47903:9195 & C & $\mathrm{T}$ & $\mathrm{T}$ & $\mathrm{T}$ & $\mathrm{T}$ & - & $\mathrm{T}$ & $\mathrm{T}$ & 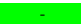 & $\mathrm{T}$ & 0 \\
\hline DAFWA1 & 0.7 & {$[\mathrm{G} / \mathrm{C}]$} & scaffold16849:33185 & $\mathrm{C}$ & G & $\mathrm{C}$ & C & - & G & G & G & G & G & 2 \\
\hline DAFWA243 & 0.7 & {$[\mathrm{C} / \mathrm{G}]$} & scaffold $16849: 22113$ & G & C & C & C & C & C & C & C & C & C & 0 \\
\hline DAFWA1910 & 0.7 & {$[\mathrm{~T} / \mathrm{C}]$} & scaffold $16849: 22233$ & $\mathrm{C}$ & $\mathrm{T}$ & $\mathrm{T}$ & $\mathrm{T}$ & $\mathrm{T}$ & $\mathrm{T}$ & $\mathrm{T}$ & $\mathrm{T}$ & $\mathrm{T}$ & $\mathrm{T}$ & 0 \\
\hline DAFWA6277 & 0.7 & {$[\mathrm{G} / \mathrm{A}]$} & scaffold $16849: 16752$ & A & G & G & G & G & G & G & G & G & G & 0 \\
\hline iDAFWA153 & 0.7 & {$[\mathrm{~T}]$} & scaffold $16849: 33300$ & del & ins & ins & ins & ins & ins & ins & ins & ins & ins & 0 \\
\hline iDAFWA390 & 0.7 & {$[\mathrm{~A}]$} & scaffold $16849: 39094$ & ins & del & ins & - & del & - & del & del & del & del & 1 \\
\hline DAFWA4236 & 0.7 & {$[\mathrm{C} / \mathrm{A}]$} & scaffold 16849:18767 & A & C & C & C & C & C & C & C & C & C & 0 \\
\hline DAFWA7175 & 0.7 & {$[\mathrm{G} / \mathrm{T}]$} & scaffold57606:11012 & $\mathrm{T}$ & G & G & G & G & G & G & G & G & G & 0 \\
\hline DAFWA8077 & 0.7 & {$[\mathrm{G} / \mathrm{A}]$} & scaffold57606:10881 & A & G & G & G & G & G & G & G & G & G & 0 \\
\hline PhtjR gene & 0.0 & & & $\mathbf{R}^{\mathrm{f}}$ & $\mathbf{S}$ & $\mathbf{s}$ & $\mathbf{s}$ & $\mathrm{s}$ & $\mathrm{s}$ & S & $\mathbf{s}$ & $\mathbf{S}$ & $\mathrm{s}$ & \\
\hline DAFWA6895 & 0.0 & {$[\mathrm{~A} / \mathrm{G}]$} & scaffold84773:23446 & G & A & G & G & A & A & A & A & A & A & 2 \\
\hline DAFWA 4020 & 0.0 & {$[\mathrm{~T} / \mathrm{G}]$} & scaffold84773:4657 & G & $\mathrm{T}$ & $\mathrm{T}$ & G & $\mathrm{T}$ & $\mathrm{T}$ & $\mathrm{T}$ & $\mathrm{T}$ & $\mathrm{T}$ & $\mathrm{T}$ & 1 \\
\hline DAFWA3123 & 0.0 & {$[\mathrm{~A} / \mathrm{G}]$} & scaffold84773:10853 & G & A & A & G & A & - & A & A & A & A & 1 \\
\hline DAFWA3340 & 1.5 & {$[\mathrm{~T} / \mathrm{A}]$} & scaffold72507:8270 & A & $\mathrm{T}$ & $\mathrm{T}$ & $\mathrm{T}$ & $\mathrm{T}$ & $\mathrm{T}$ & $\mathrm{T}$ & $\mathrm{T}$ & $\mathrm{T}$ & $\mathrm{T}$ & 0 \\
\hline iDAFWA109 & 1.5 & {$[\mathrm{~A}]$} & scaffold $72507: 4453$ & del & ins & del & del & ins & ins & ins & ins & ins & - & 2 \\
\hline DAFWA168 & 2.9 & {$[\mathrm{~A} / \mathrm{C}]$} & scaffold70674:5746 & $\mathrm{C}$ & A & C & C & A & A & - & A & A & C & 3 \\
\hline DAFWA4021 & 4.4 & {$[\mathrm{~A} / \mathrm{G}]$} & scaffold $97302: 722$ & G & A & A & G & - & A & - & A & A & G & 2 \\
\hline DAFWA8465 & 4.4 & {$[\mathrm{G} / \mathrm{A}]$} & scaffold97302:774 & A & G & G & A & - & G & - & G & G & G & 1 \\
\hline DAFWA2783 & 4.4 & {$[\mathrm{~T} / \mathrm{C}]$} & scaffold64722:1309 & $\mathrm{C}$ & $\mathrm{T}$ & - & C & $\mathrm{T}$ & $\mathrm{T}$ & $\mathrm{T}$ & $\mathrm{T}$ & $\mathrm{T}$ & $\mathrm{T}$ & 1 \\
\hline DAFWA5392 & 4.4 & {$[\mathrm{~A} / \mathrm{T}]$} & scaffold64722:3001 & $\mathrm{T}$ & A & A & $\mathrm{T}$ & A & A & A & A & A & A & 1 \\
\hline DAFWA4743 & 4.4 & {$[\mathrm{C} / \mathrm{T}]$} & scaffold $46722: 492$ & $\mathrm{~T}$ & C & C & C & 12 & C & C & $\mathrm{C}$ & $\mathrm{C}$ & $\mathrm{C}$ & 0 \\
\hline DAFWA7048 & 4.4 & {$[\mathrm{~A} / \mathrm{G}]$} & scaffold75111:27072 & G & A & G & A & A & 2 & A & A & A & A & 1 \\
\hline
\end{tabular}

${ }^{a}$ Markers showing genotypes completely consistent with PSB disease phenotypes on all 10 cultivars are considered candidate diagnostic markers and are highlighted in green

${ }^{\mathrm{b}}$ Two nucleotides separated by a stroke line in brackets are SNP markers; nucleotides in brackets without a stroke line are InDel markers

${ }^{c}$ Marker positions are the nucleotide positions on the reference genome sequence assembly from cultivar Tanjil (Genbank BioProject number PRJNA179231)

${ }^{\mathrm{d}}$ Markers showing R-allele genotype on cultivars without the R gene Phtj (false positives) are highlighted in red

"Marker sequences missing in genome re-sequencing were recorded as missing data "_"

${ }^{\mathrm{f}}$ Genotypes of R gene PhtjR on sequenced cultivars presented in blue: $\mathrm{R}=$ presence of $P h t j R$ gene; $\mathrm{S}=$ absence of $P h t j R$ gene [44]

SNP263, had genotypes consistent with PSB phenotypes, and were diagnostic for the $\mathrm{R}$ gene PhtjR (Table 10). On these 27 cultivars, false positives were discovered on SNP271 (1), SNP250 (6) and SNP264 (17) (Table 10). Two InDel markers, InDel2 and InDel10, were diagnostic on all 27 cultivars, while InDel28 and InDel66 had four and eight false positives, respectively (Fig. 3).

\section{Linkage confirmation, validation, and application of established markers}

The two sequence-specific, PCR-based SNP markers developed from genotyping markers from the genetic linkage map, DAFWA6277 and DAFWA8077, were successfully genotyped on the $\mathrm{F}_{8}$ population containing 186 RILs segregating for the R gene PhtjR [44]. Linkage analysis using the software program MapManager [50] based on marker genotypes and PSB disease phenotypes confirmed that these two markers are linked to the $\mathrm{R}$ gene PhtjR with a genetic distance of $1.1 \mathrm{cM}$, which would be approximately $99 \%$ accurate for selecting lupin progeny with the $\mathrm{R}$ gene for MAS.

Three of the sequence-specific, PCR-based markers arising from marker mining on scaffold87443 developed this study-SNP20, SNP25 and InDel10-were genotyped on the $\mathrm{F}_{8}$ RIL population derived from the Unicrop $\times$ Tanjil cross which was segregating for the PhtjR gene [44]. All three markers had marker genotypes completely consistent with PSB disease phenotypes on all 186 RILs (co-segregating). Further validation identified marker genotypes consistent with PSB disease phenotypes on all 69 advanced breeding lines and 163 parental lines used for crossing in the Australian lupin breeding program.

The genetic linkage analysis and validation tests confirmed that markers developed through the two different approaches in this study were all superior to previously developed markers [44] both in accuracy and in wide applicability. The two SNP markers, SNP20 and SNP25, which fit well with the cost-effective, high-throughput SNP genotyping platform LightScanner, have been applied for MAS in the Australian lupin breeding program.

\section{Discussion}

Genome sequence is a fundamental knowledge in understanding the genomics, genetic and biology in plants. Thanks to the advancements in parallel sequencing technologies in recent years, tens of thousands of genomes are in the process of being sequenced [51]. At current time, "close-to-complete genome sequences" have only been achieved on a few model plant species, such as Arabidopsis, rice, Brachypodium, and Medicago [51, 52] where DNA sequences are available almost continuously from the beginning to the end of each chromosome in the genomes. The 
Table 6 Conversion of SNP markers identified from genotyping markers on genetic linkage map flanking the R gene PhtjR into sequence-specific PCR markers suitable for genotyping by high resolution melting (HRM) with LightScanner

\begin{tabular}{|c|c|c|}
\hline Marker & Primers & Primer sequence $\left(5^{\prime}-3^{\prime}\right)$ \\
\hline \multirow[t]{2}{*}{ DAFWA926 } & DAFWA926F & GGTTGGGTTAACTTITATGTCTAAAATC \\
\hline & DAFWA926R & GGTAAGTTATTITCTAAAGTTGAAC \\
\hline \multirow[t]{2}{*}{ DAFWA2836 } & DAFWA2836F & CACATAAGAATATGGAAATGGAGA \\
\hline & DAFWA2836R & CTGTAAACTGAAGGTGGGCATT \\
\hline \multirow[t]{2}{*}{ DAFWA3794 } & DAFWA3794F & GAAAGGAGAAAACTAATCAACATAAG \\
\hline & DAFWA3794R & ATTAGGGTTTGAGATAGAGTAACAT \\
\hline \multirow[t]{2}{*}{ DAFWA2747 } & DAFWA2747F & CCTAACTTCCGATCCAGTAAGC \\
\hline & DAFWA2747R & CTITGATCGCTTGGGTTTC \\
\hline \multirow[t]{2}{*}{ DAFWA6277 } & DAFWA6277F & TTCGGGAATTTGTATGAGCT \\
\hline & DAFWA6277R & GGATGGATTCAAAGGTTCAAG \\
\hline \multirow[t]{2}{*}{ DAFWA8077 } & DAFWA8077F & GAGATTATTTTCACAAGCTTCCTC \\
\hline & DAFWA8077R & CCTITAGCTTATTCAATTAGCTTG \\
\hline \multirow[t]{2}{*}{ DAFWA6895 } & DAFWA6895F & TGAAGGTCCAATACCAGCAAG \\
\hline & DAFWA6895R & CAACTTCCCTGGAGCAAAA \\
\hline \multirow[t]{2}{*}{ DAFWA4020 } & DAFWA4020F & CTAGATAGTITCGTITIATCATAC \\
\hline & DAFWA4020R & GACATAAAGCTTATATATTTGCA \\
\hline \multirow[t]{2}{*}{ DAFWA3123 } & DAFWA3123F & CCCTGGACTCTCTCCCTGTATT \\
\hline & DAFWA3123R & GAATGAAAGTTTGATATGCATAATAA \\
\hline \multirow[t]{2}{*}{ DAFWA4021 } & DAFWA4021F & GCTCAGAAACGGTGTCGTT \\
\hline & DAFWA4021R & GAAGACCTCCAAAACCAAAGC \\
\hline
\end{tabular}

lengths of sequence span of "complete" genome sequences are equal to the plant genome sizes. However, the majority of other published plant genomes are still at "draft" stage, where genome sequences are presented as large pieces of scaffold sequences. The scaffolds sequences can be aligned into each chromosome through the help of dense genetic linkage maps [53, 54], but many gaps exist between scaffolds on each chromosome. The sequence spans of "draft" genome sequences are smaller than the genome sizes. For examples, the length span of recently released high-depth (358X) genome sequence (1.34Gb) reached to $89.3 \%$ coverage of the oak tree genome size (1.5Gb) [55]; the length of the genome sequence reported on Setaria (396.7 Mbp) was $77.8 \%$ of the genome size (510 Mbp) [54]; the length of the cucumber genome sequence published (243.5 Mbp) was approximately $66 \%$ of the genome size (367 Mbp) [56]. The two major challenges for obtaining complete genome sequences in plant genome sequencing projects are the large genome sizes and the repetitive sequences [52]. The lupin draft genome sequence has a relatively low genome coverage at $51.9 \%$ [38], which was duo to three factors: the lupin genome size is pretty large (at $1.153 \mathrm{~Gb}$ ) [38]; the genome is rich in repetitive sequences [34]; and the draft sequence was generated from a low costing sequencing project (equivalent to US\$5,000) originated from two sequencing libraries with sequencing depth only at 27X [38]. In this study, the genome sequencing and re-sequencing data were used in the identification and selection of candidate diagnostic markers linked to a gene conferring disease resistance. The final selected candidate markers then went through the genetic linkage confirmation step and validation step in the same way as in other standard marker development methods [16, 21, 37]. The linkage confirmation and validation steps ensured that the final markers recommended for MAS were single copy in the genome, were closely linked to gene of interest, were applicable to wide range of breeding germplasm, and were desirable for marker-assisted plant breeding. There are lively discussions among plant scientists about what more can be gained from an in-depth, time-consuming and costly effort to generate high-quality complete sequences than from low coverage draft genome sequences [52]. The results in this study have demonstrated that low coverage genome sequencing and re-sequencing data were sufficient and very effective on marker development in molecular plant breeding. The same low coverage lupin genome sequence was also very successful in the discovery of a candidate gene based diagnostic markers linked to anthracnose disease resistance [38], and in the conversion of previously established gel-based InDel markers into SNP markers to suit modern SNP genotyping platforms for marker implementation in lupin breeding [51].

This study was the first attempt at whole genome resequencing of the legume crop species L. angustifolius following a 2013 report on its draft genome sequence [38]. Comparing the genome sequences of 10 sequenced cultivars identified 0.3 to 0.6 million molecular markers, which demonstrated the power of whole genome sequencing and re-sequencing for marker discovery. These markers provide lupin breeders and molecular geneticists with a broader suite of options for a wide range of breeding and research purposes. Lupin is a relatively new agricultural crop, domesticated in the early 1970s from its wild relatives. The abundance of SNP and InDel markers among commercial cultivars reflects the rich genetic diversity of the wild parental lines used in the domestication and breeding efforts over the last 40 years. It is evident that the selection pressure for certain desirable agronomic traits of interest in the lupin breeding program had a major impact on genetic diversity at chromosome level. For example, anthracnose disease caused a serious epidemic in Australia in 1996. A major R gene, Lanr1, had been exclusively utilized by the lupin breeding program to combat the disease since 1996 [22]; which resulted in the lower genetic diversity in SLG-1 where the Lanr1 gene was mapped among the recently released commercial cultivars. In contrast, there are at least three major $\mathrm{R}$ genes each independently conferring 
Table 7 Validation of sequence-specific SNP markers identified from genotyping markers on a genetic linkage map flanking the R gene PhtjR conferring resistance to phomopsis stem blight disease on all historical and current commercial cultivars of Lupinus angustifolius released in Australia

\begin{tabular}{|c|c|c|c|c|c|c|c|c|c|c|c|c|}
\hline \multirow[t]{2}{*}{ Cultivar } & \multirow[t]{2}{*}{$\begin{array}{l}\text { Year of } \\
\text { release }\end{array}$} & \multirow[t]{2}{*}{$\begin{array}{l}\text { PhtjR gene } \\
\text { phenotype }^{\mathrm{a}}\end{array}$} & $\begin{array}{c}\text { DAFWA } \\
926\end{array}$ & $\begin{array}{c}\text { DAFWA } \\
2836\end{array}$ & $\begin{array}{c}\text { DAFWA } \\
3794\end{array}$ & $\begin{array}{c}\text { DAFWA } \\
2747\end{array}$ & $\begin{array}{c}\text { DAFWA } \\
6277\end{array}$ & $\begin{array}{c}\text { DAFWA } \\
8077\end{array}$ & $\begin{array}{c}\text { DAFWA } \\
6895 \\
\end{array}$ & $\begin{array}{c}\text { DAFWA } \\
4020\end{array}$ & $\begin{array}{c}\text { DAFWA } \\
3123 \\
\end{array}$ & $\begin{array}{c}\text { DAFWA } \\
4021\end{array}$ \\
\hline & & & $5.1^{\mathrm{b}}$ & 5.1 & 2.1 & 2.1 & 0.7 & 0.7 & 0 & 0 & 0 & 4.4 \\
\hline Uniwhite & 1967 & $\mathbf{S}$ & S & $\mathrm{S}$ & $\mathrm{S}$ & $\mathrm{S}$ & $\mathrm{S}$ & $\mathrm{S}$ & $\mathrm{S}$ & $\mathrm{S}$ & $\mathrm{S}$ & $\mathrm{S}$ \\
\hline Uniharvest & 1971 & $\mathbf{S}$ & $\mathrm{S}$ & S & $\mathrm{S}$ & $\mathrm{S}$ & $\mathrm{S}$ & $\mathrm{S}$ & $\mathrm{S}$ & $\mathrm{S}$ & $\mathrm{S}$ & $\mathrm{S}$ \\
\hline Unicrop & 1973 & $\mathbf{S}$ & S & S & S & $\mathrm{S}$ & S & $\mathrm{S}$ & $\mathrm{S}$ & $\mathrm{S}$ & $\mathrm{S}$ & $\mathrm{S}$ \\
\hline Marri & 1976 & $\mathbf{S}$ & $\mathrm{S}$ & S & $S$ & $\mathrm{~S}$ & $\mathrm{~S}$ & $\mathrm{~S}$ & $\mathrm{~S}$ & $\mathrm{~S}$ & $\mathrm{~S}$ & $\mathrm{~S}$ \\
\hline Illyarrie & 1979 & $\mathbf{S}$ & $S$ & S & $S$ & $\mathrm{~S}$ & S & S & $\mathrm{S}$ & $\mathrm{S}$ & $\mathrm{S}$ & $\mathrm{S}$ \\
\hline Yandee & 1980 & $\mathbf{S}$ & S & S & S & $\mathrm{S}$ & $\mathrm{S}$ & $\mathrm{S}$ & $\mathrm{S}$ & $\mathrm{S}$ & $\mathrm{S}$ & $\mathrm{S}$ \\
\hline Chittick & 1982 & $\mathbf{S}$ & $\mathrm{S}$ & $\mathrm{S}$ & $\mathrm{S}$ & $\mathrm{S}$ & $\mathrm{S}$ & $\mathrm{S}$ & $\mathrm{S}$ & $\mathrm{S}$ & $\mathrm{S}$ & $\mathrm{S}$ \\
\hline Danja & 1986 & $\mathbf{S}$ & $\mathrm{S}$ & S & $\mathrm{S}$ & $\mathrm{S}$ & S & $\mathrm{S}$ & $\mathrm{S}$ & $\mathrm{S}$ & $\mathrm{S}$ & $\mathrm{S}$ \\
\hline Geebung & 1987 & $\mathbf{S}$ & $S$ & S & S & $\mathrm{S}$ & $\mathrm{S}$ & $\mathrm{S}$ & $\mathrm{S}$ & $\mathrm{S}$ & $\mathrm{S}$ & $\mathrm{S}$ \\
\hline Gungurru & 1988 & $\mathbf{S}$ & $\mathrm{S}$ & S & S & $\mathrm{R}^{\mathrm{c}}$ & S & $\mathrm{S}$ & $\mathrm{R}$ & $\mathrm{S}$ & $\mathrm{S}$ & $\mathrm{S}$ \\
\hline Yorrel & 1989 & $\mathbf{S}$ & $S$ & S & S & $\mathrm{R}$ & $\mathrm{S}$ & $\mathrm{S}$ & $\mathrm{R}$ & $\mathrm{R}$ & $\mathrm{R}$ & $\mathrm{R}$ \\
\hline Warrah & 1989 & $\mathbf{S}$ & S & S & S & $S$ & $\mathrm{~S}$ & $\mathrm{~S}$ & $\mathrm{R}$ & $\mathrm{R}$ & $\mathrm{R}$ & $\mathrm{R}$ \\
\hline Merrit & 1991 & $\mathbf{S}$ & $\mathrm{S}$ & $\mathrm{S}$ & S & $\mathrm{R}$ & $\mathrm{S}$ & $\mathrm{S}$ & $\mathrm{R}$ & $\mathrm{R}$ & $\mathrm{R}$ & $\mathrm{R}$ \\
\hline Myallie & 1995 & $\mathbf{S}$ & S & S & S & $\mathrm{S}$ & $\mathrm{S}$ & $\mathrm{S}$ & $\mathrm{S}$ & $\mathrm{S}$ & $\mathrm{S}$ & $\mathrm{S}$ \\
\hline Kalya & 1996 & $\mathbf{S}$ & $\mathrm{S}$ & $\mathrm{S}$ & S & $\mathrm{S}$ & $\mathrm{S}$ & $\mathrm{S}$ & $\mathrm{S}$ & $\mathrm{S}$ & $\mathrm{S}$ & $\mathrm{S}$ \\
\hline Wonga & 1996 & $\mathbf{R}$ & $\mathrm{R}$ & $\mathrm{R}$ & $\mathrm{R}$ & $\mathrm{R}$ & $\mathrm{R}$ & $\mathrm{R}$ & $\mathrm{R}$ & $\mathrm{R}$ & $\mathrm{R}$ & $\mathrm{R}$ \\
\hline Belara & 1997 & $\mathbf{S}$ & S & S & S & S & $\mathrm{S}$ & $\mathrm{S}$ & $\mathrm{S}$ & $\mathrm{S}$ & $\mathrm{S}$ & S \\
\hline Tallerack & 1997 & $\mathbf{S}$ & S & S & S & $\mathrm{S}$ & S & S & $\mathrm{S}$ & $\mathrm{S}$ & $\mathrm{S}$ & $\mathrm{S}$ \\
\hline Tanjil & 1998 & $\mathbf{R}$ & $\mathrm{R}$ & $\mathrm{R}$ & $\mathrm{R}$ & $\mathrm{R}$ & $\mathrm{R}$ & $\mathrm{R}$ & $\mathrm{R}$ & $\mathrm{R}$ & $\mathrm{R}$ & $\mathrm{R}$ \\
\hline Moonah & 1998 & $\mathbf{S}$ & $\mathrm{S}$ & S & S & $\mathrm{R}$ & $\mathrm{S}$ & $\mathrm{S}$ & $\mathrm{R}$ & $\mathrm{R}$ & $\mathrm{R}$ & $\mathrm{R}$ \\
\hline Quilinock & 1999 & $\mathbf{S}$ & $\mathrm{S}$ & S & S & $\mathrm{S}$ & $\mathrm{S}$ & $\mathrm{S}$ & $\mathrm{S}$ & $\mathrm{S}$ & $\mathrm{S}$ & $\mathrm{R}$ \\
\hline Jindalee & 2000 & $\mathbf{S}$ & S & S & S & $\mathrm{R}$ & $\mathrm{S}$ & $\mathrm{S}$ & $\mathrm{R}$ & $\mathrm{R}$ & $\mathrm{R}$ & $\mathrm{R}$ \\
\hline Mandelup & 2004 & $\mathbf{S}$ & S & S & S & $\mathrm{S}$ & $\mathrm{S}$ & $\mathrm{S}$ & $\mathrm{S}$ & $\mathrm{S}$ & $\mathrm{S}$ & $\mathrm{S}$ \\
\hline Coromup & 2006 & $\mathbf{S}$ & $\mathrm{S}$ & $\mathrm{S}$ & $\mathrm{S}$ & $\mathrm{R}$ & $\mathrm{S}$ & $\mathrm{S}$ & $\mathrm{R}$ & $\mathrm{S}$ & $\mathrm{S}$ & S \\
\hline Jenabillup & 2007 & $\mathbf{S}$ & S & S & S & $\mathrm{S}$ & $\mathrm{S}$ & $\mathrm{S}$ & $\mathrm{S}$ & $\mathrm{S}$ & $\mathrm{S}$ & $\mathrm{R}$ \\
\hline Gunyidi & 2011 & $\mathbf{S}$ & $S$ & $\mathrm{~S}$ & S & $\mathrm{R}$ & $\mathrm{S}$ & $\mathrm{S}$ & $\mathrm{R}$ & $\mathrm{R}$ & $\mathrm{R}$ & $\mathrm{R}$ \\
\hline Barlock & 2013 & $\mathbf{R}$ & $\mathrm{R}$ & $\mathrm{R}$ & $\mathrm{R}$ & $\mathrm{R}$ & $\mathrm{R}$ & $\mathrm{R}$ & $\mathrm{R}$ & $\mathrm{R}$ & $\mathrm{R}$ & $\mathrm{R}$ \\
\hline $\mathrm{Nu}$ & of "false & ves" & $0^{\mathrm{d}}$ & 0 & 0 & 7 & 0 & 0 & 8 & 6 & 6 & 8 \\
\hline
\end{tabular}

${ }^{\mathrm{a}}$ Genotypes of $\mathrm{R}$ gene PhtjR on commercial cultivars are presented as: $\mathrm{R}=$ presence of PhtjR gene; $\mathrm{S}=$ absence of PhtjR gene [44]

${ }^{\mathrm{b}}$ Genetic distance of the marker to the R gene PhtjR in centiMorgans (cM) was adapted from the mapping studies [38]

${ }^{c}$ Markers showing R-allele genotype on cultivars without the $\mathrm{R}$ gene (false positives) are in highlighted in red

${ }^{d}$ SNP markers showing marker genotypes completely consistent with the PhtjR gene phenotypes in all 27 commercial cultivars (no false positive) are diagnostic markers, and are highlighted in green

resistance to phomopsis stem blight disease applied in the Australian lupin breeding program [44]; the lack of selection pressure for $P h t j R$ gene has helped to preserve the genetic diversity in SLG-11 where the PhtjR gene was mapped.
Genetic mapping is a commonly-used approach for marker-trait association discovery in plant molecular studies. In the last three decades, genetic linkage maps have been constructed for most cultivated grain crops. The application of NGS and genome sequencing in recent
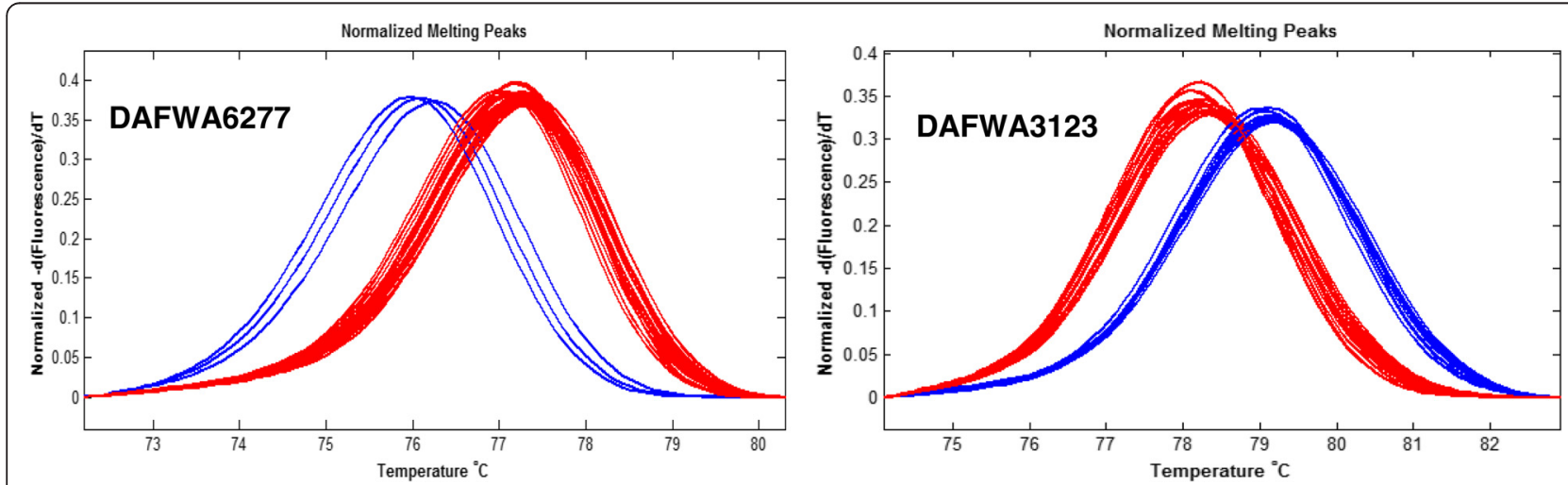

Fig. 2 Validation of simple PCR-based SNP markers linked to the R gene PhtiR conferring phomopsis stem blight disease resistance on all 27 historical and current cultivars of Lupinus angustifolius released in Australia by high resolution melting (HRM) on LightScanner. SNP marker DAFWA6277 (left) was confirmed as diagnostic for the PhtjR gene, as the three cultivars (Wonga, Tanjil and Barlock) showed the resistance marker allele (melting curves in blue), while all the other 23 cultivar not possessing the R gene has the susceptible marker allele (melting curves in red). In contrast, SNP marker DAFWA3123 (right) was confirmed as non-diagnostic, since six cultivars (Table 7) without the $\mathrm{R}$ gene had the resistance marker allele (melting curves in blue). Detailed records of genotypes for 27 cultivars of these two markers are presented in Table 7 
Table 8 List of a small portion of SNP markers and InDel markers discovered by marker mining on scaffold84773 (Genbank accession \# AOCW01145302) showing large variation in marker genotypes among 10 sequenced cultivars and identification of candidate diagnostic markers for the $\mathrm{R}$ gene PhtjR of Lupinus angustifolius ${ }^{\mathrm{a}}$

\begin{tabular}{|c|c|c|c|c|c|c|c|c|c|c|c|c|c|}
\hline & Marker variation & $\begin{array}{l}\text { Marker position on } \\
\text { reference scaffolds } \\
\text { (Genbank acc \# } \\
\text { AOCW01145302) } \\
\end{array}$ & Tanjil & Unicrop & Yorrel & Merrit & Kalya & Tallerack & Quilinock & Mandelup & Coromup & Jenabillup & $\begin{array}{l}\text { Number of } \\
\text { "false } \\
\text { positives" b }\end{array}$ \\
\hline $\begin{array}{l}\text { R gene Phtj } \\
\text { phenotype }\end{array}$ & & & $\mathrm{R}$ & S & S & S & $\mathrm{S}$ & s & S & s & S & S & \\
\hline SNP20 $0^{\circ}$ & {$[\mathrm{T} / \mathrm{C}]$} & 890 & $\mathrm{C}$ & $\mathrm{T}$ & $\mathrm{T}$ & $\mathrm{T}$ & $\mathrm{T}$ & $\mathrm{T}$ & $\mathrm{T}$ & $\mathrm{T}$ & $\mathrm{T}$ & $\mathrm{T}$ & 0 \\
\hline SNP25 & {$[\mathrm{C} / \mathrm{T}]$} & 988 & $\mathrm{~T}$ & C & $\mathrm{C}$ & $\mathrm{C}$ & $\mathrm{C}$ & $\mathrm{C}$ & C & $\mathrm{C}$ & $\mathrm{C}$ & $\mathrm{C}$ & 0 \\
\hline SNP250 & [C/A] & 8776 & A & C & A & A & $\mathrm{C}$ & C & C & C & C & C & 2 \\
\hline SNP263 & {$[\mathrm{C} / \mathrm{T}]$} & 9236 & $\mathrm{~T}$ & C & $\mathrm{C}$ & C & C & C & C & C & C & C & 0 \\
\hline SNP 264 & {$[\mathrm{~T} / \mathrm{C}]$} & 9401 & $\mathrm{C}$ & C & $\mathrm{T}$ & $\mathrm{T}$ & C & C & C & C & C & C & 7 \\
\hline SNP 267 & {$[\mathrm{G} / \mathrm{T}]$} & 9912 & $\mathrm{~T}$ & $\mathrm{~T}$ & $\mathrm{~T}$ & G & $\mathrm{T}$ & $\mathrm{T}$ & $\mathrm{T}$ & $\mathrm{T}$ & $\mathrm{T}$ & $\mathrm{T}$ & 8 \\
\hline SNP 268 & [G/A] & 9923 & A & G & A & A & G & G & G & G & G & G & 2 \\
\hline SNP271 & {$[\mathrm{T} / \mathrm{C}]$} & 10051 & $\mathrm{C}$ & $\mathrm{T}$ & $\mathrm{T}$ & $\mathrm{T}$ & $\mathrm{T}$ & $\mathrm{T}$ & $\mathrm{T}$ & $\mathrm{T}$ & $\mathrm{T}$ & $\mathrm{T}$ & 0 \\
\hline SNP 272 & {$[\mathrm{~T} / \mathrm{G}]$} & 10085 & G & G & $\mathrm{T}$ & G & G & G & G & G & G & G & 8 \\
\hline SNP281 & {$[\mathrm{A} / \mathrm{G}]$} & 10853 & G & A & A & G & A & A & A & A & A & A & 1 \\
\hline InDel2 & [CAATAAAAATAT] & $275-286$ & ins & del & del & del & del & del & del & del & del & del & 0 \\
\hline InDel10 & [GACAAAT] & $919-925$ & ins & del & del & del & del & del & del & del & del & del & 0 \\
\hline InDel28 & [CAAATAGCCACA] & 3185-3196 & ins & del & del & ins & del & del & del & del & del & del & 1 \\
\hline InDel66 & $\begin{array}{l}\text { [CAATTTTATAATT } \\
\text { AAATATG] }\end{array}$ & 25036 & del & ins & del & del & ins & ins & ins & ins & ins & ins & 2 \\
\hline
\end{tabular}

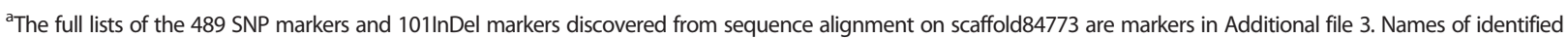
markers are consistent with the names labelled numerically in Additional file 3

${ }^{\mathrm{b}}$ Markers showing R-allele genotypes on cultivars without the $\mathrm{R}$ gene PhtjR (false positives) are in highlighted in red

${ }^{c}$ Markers showing genotypes consistent with disease resistance phenotypes on all 10 sequenced cultivars are considered as candidate diagnostic markers, and are highlighted in green

Table 9 Conversion of SNP markers and InDel markers arising from marker mining on scaffold84773 into sequence-specific PCR markers in Lupinus angustifolius

\begin{tabular}{|c|c|c|}
\hline Marker name & Primers & Primer sequence $\left(5^{\prime}-3^{\prime}\right)$ \\
\hline \multirow[t]{2}{*}{ SNP 20} & SNP2OF & GTCCCTGCCATTATTAATAGTTACT \\
\hline & SNP20R & CATCATGAGTCAATTTACCACTTA \\
\hline \multirow[t]{2}{*}{ SNP 25} & SNP25F & GTCACTAATTTTATCTTTGCAAGA \\
\hline & SNP25R & GATCATAAGAATAATAATAATAATTTGGT \\
\hline \multirow[t]{2}{*}{ SNP 250} & SNP250F & GACTTAGTAATGTGCAACAAGAG \\
\hline & SNP250R & CTGACACTACAGGTTCGCCT \\
\hline \multirow[t]{2}{*}{ SNP 263} & SNP263F & GGAACATTGTGATTCAGTCACC \\
\hline & SNP263R & GATAGGTTTGTTGCAATAAGCG \\
\hline \multirow[t]{2}{*}{ SNP264 } & SNP264F & GTITCTTAGTTGCATAGTTGCAA \\
\hline & SNP264R & CAAAACATTCATAAGTAACAAGG \\
\hline \multirow[t]{2}{*}{ SNP271 } & SNP271F & CGACACCATCTGATATATGAAAATAA \\
\hline & SNP271R & ACCGGAAATCTGTGTTITC \\
\hline \multirow[t]{2}{*}{ InDel2 } & InDel2F & GATAAAGTATATCTAAATTATGTTTGC \\
\hline & InDel2R & CTATATTTTGTATCAATTATAACAAATT \\
\hline \multirow[t]{2}{*}{ InDel10 } & InDel10F & GTTAAGTGGTAAATTGACTCATG \\
\hline & InDel10R & GTTTRCATTCTTGCAAAGATAAAATTAG \\
\hline \multirow[t]{2}{*}{ InDel28 } & InDel28F & CTACAATAGCCACACAAATAG \\
\hline & InDel28R & GTTAGATGGCCMTGTGC \\
\hline \multirow[t]{2}{*}{ InDel66 } & InDel66F & CTTCTGAGTTGGACCATAAAC \\
\hline & InDel66R & ACTCACATTTACAGAACTTTAACT \\
\hline
\end{tabular}

years has enhanced the power of plant genetic mapping. For example, a genotyping by sequencing (GBS) study discovered and mapped 416,856 markers in wheat [57]; a whole genome sequencing study on a $\mathrm{F}_{8}$ RIL population in rice mapped 1,226,791 SNP markers [58]; and sequencing and physical mapping identified 1,013,161-2,053,580 SNP markers in each of four mapping populations in barley [59]. In this study, we anchored 207,887 markers on the lupin genetic linkage map. In theory, all markers with known DNA sequences on genetic linkage maps can be genotyped by whole genome sequencing and re-sequencing data. With so many markers available on genetic linkage maps, the genes of interest to breeders are usually flanked by a large number of markers, which provides ample choice for identifying diagnostic markers desirable for MAS. Yet with traditional methods, identifying diagnostic markers through conversion and validation tests on a large number of markers is tedious and time consuming. Whole genome sequencing and re-sequencing has been demonstrated in this study to be a powerful approached to select diagnostic markers from genetic maps. The 10 lupin cultivars used in the genome sequencing and re-sequencing in this study were carefully selected based on their pedigree kinship to represent genetic diversity in commercial cultivars released in Australia. Therefore, most of the candidate diagnostic markers identified from genotyping these cultivars were validated as truly diagnostic on a wide range of historical and current commercial cultivars. Two of the sequence-specific, simple PCR-based SNP markers developed in this study, DAFWA6277 and DAFWA8077, meet the two key requirements for MAS of being "diagnostic" and "closely linked $(1.1 \mathrm{cM})$ to the target gene of interest". 
Table 10 Validation of sequence-specific SNP and InDel markers arising from marker mining on scaffold84773 linked the R gene PhtjR conferring resistance to PSB disease on all historical and current commercial cultivars of Lupinus angustifolius released in Australia

\begin{tabular}{|c|c|c|c|c|c|c|c|c|c|c|c|}
\hline Cultivar & $\begin{array}{c}\text { Phenotypes of } \\
\text { Phtj gene }{ }^{\mathrm{a}}\end{array}$ & SNP 20 & SNP 25 & SNP 250 & SNP263 & SNP264 & SNP271 & InDel2 & InDel10 & InDel28 & InDel66 \\
\hline Uniwhite & S & $\mathrm{S}$ & $\mathrm{S}$ & S & $\mathrm{S}$ & $\mathrm{R}^{\mathrm{b}}$ & $\mathrm{S}$ & $\mathrm{S}$ & S & S & $\mathrm{S}$ \\
\hline Uniharvest & $\mathrm{S}$ & $\mathrm{S}$ & $\mathrm{S}$ & $\mathrm{S}$ & $\mathrm{S}$ & $\mathrm{R}$ & $\mathrm{S}$ & $\mathrm{S}$ & $\mathrm{S}$ & $\mathrm{S}$ & $\mathrm{S}$ \\
\hline Unicrop & $S$ & S & S & S & S & $\mathrm{R}$ & S & S & $S$ & $S$ & S \\
\hline Marri & $\mathrm{S}$ & $\mathrm{S}$ & $\mathrm{S}$ & $\mathrm{S}$ & $\mathrm{S}$ & $\mathrm{R}$ & $\mathrm{S}$ & $\mathrm{S}$ & $\mathrm{S}$ & $\mathrm{S}$ & $\mathrm{S}$ \\
\hline Illyarrie & $\mathrm{S}$ & $\mathrm{S}$ & $\mathrm{S}$ & $\mathrm{S}$ & $\mathrm{S}$ & $\mathrm{R}$ & $\mathrm{S}$ & $\mathrm{S}$ & $\mathrm{S}$ & $\mathrm{S}$ & $\mathrm{S}$ \\
\hline Yandee & $\mathrm{S}$ & $\mathrm{S}$ & $\mathrm{S}$ & $\mathrm{S}$ & S & $\mathrm{R}$ & $\mathrm{S}$ & $\mathrm{S}$ & $\mathrm{S}$ & $\mathrm{S}$ & $\mathrm{S}$ \\
\hline Chittick & $\mathrm{S}$ & S & S & $\mathrm{S}$ & $\mathrm{S}$ & $\mathrm{R}$ & $\mathrm{S}$ & $\mathrm{S}$ & $\mathrm{S}$ & $\mathrm{S}$ & $\mathrm{S}$ \\
\hline Danja & S & S & S & S & $\mathrm{S}$ & $\mathrm{R}$ & S & $\mathrm{S}$ & S & S & $S$ \\
\hline Geebung & $\mathrm{S}$ & $\mathrm{S}$ & $\mathrm{S}$ & $\mathrm{S}$ & $\mathrm{S}$ & $\mathrm{R}$ & $\mathrm{S}$ & $\mathrm{S}$ & $\mathrm{S}$ & $\mathrm{S}$ & $\mathrm{S}$ \\
\hline Gungurru & S & S & S & $\mathrm{R}$ & $\mathrm{S}$ & $\mathrm{R}$ & $S$ & S & S & $\mathrm{R}$ & $\mathrm{R}$ \\
\hline Yorrel & $\mathrm{S}$ & $\mathrm{S}$ & $\mathrm{S}$ & $\mathrm{R}$ & S & $\mathrm{S}$ & $\mathrm{S}$ & $\mathrm{S}$ & $\mathrm{S}$ & $\mathrm{S}$ & $\mathrm{R}$ \\
\hline Warrah & $\mathrm{S}$ & $\mathrm{S}$ & $\mathrm{S}$ & $\mathrm{R}$ & $\mathrm{S}$ & $\mathrm{S}$ & $\mathrm{S}$ & $\mathrm{S}$ & $\mathrm{S}$ & $\mathrm{S}$ & $\mathrm{R}$ \\
\hline Merrit & $\mathrm{S}$ & $\mathrm{S}$ & $\mathrm{S}$ & $\mathrm{R}$ & $\mathrm{S}$ & $\mathrm{S}$ & $\mathrm{S}$ & $\mathrm{S}$ & $\mathrm{S}$ & $\mathrm{R}$ & $\mathrm{R}$ \\
\hline Myallie & $\mathrm{S}$ & S & S & $\mathrm{S}$ & $\mathrm{S}$ & $\mathrm{R}$ & $\mathrm{S}$ & $\mathrm{S}$ & $\mathrm{S}$ & $\mathrm{S}$ & $\mathrm{S}$ \\
\hline Kalya & $\mathrm{S}$ & $\mathrm{S}$ & $\mathrm{S}$ & $\mathrm{S}$ & S & $\mathrm{R}$ & $\mathrm{R}$ & $\mathrm{S}$ & $\mathrm{S}$ & $\mathrm{S}$ & $\mathrm{S}$ \\
\hline Wonga & $\mathrm{R}$ & $\mathrm{R}$ & $\mathrm{R}$ & $\mathrm{R}$ & $\mathrm{R}$ & $\mathrm{R}$ & $\mathrm{R}$ & $\mathrm{R}$ & $\mathrm{R}$ & $\mathrm{R}$ & $\mathrm{R}$ \\
\hline Belara & $\mathrm{S}$ & $\mathrm{S}$ & $\mathrm{S}$ & $\mathrm{S}$ & $\mathrm{S}$ & $\mathrm{R}$ & $\mathrm{S}$ & $\mathrm{S}$ & $\mathrm{S}$ & $\mathrm{S}$ & $\mathrm{R}$ \\
\hline Tallerack & $\mathrm{S}$ & $\mathrm{S}$ & $\mathrm{S}$ & $\mathrm{S}$ & $\mathrm{S}$ & $\mathrm{R}$ & $\mathrm{S}$ & $\mathrm{S}$ & $\mathrm{S}$ & $\mathrm{S}$ & $\mathrm{S}$ \\
\hline Tanjil & $\mathrm{R}$ & $\mathrm{R}$ & $\mathrm{R}$ & $\mathrm{R}$ & $\mathrm{R}$ & $\mathrm{R}$ & $\mathrm{R}$ & $\mathrm{R}$ & $\mathrm{R}$ & $\mathrm{R}$ & $\mathrm{R}$ \\
\hline Moonah & S & $\mathrm{S}$ & $\mathrm{S}$ & $\mathrm{S}$ & $\mathrm{S}$ & $\mathrm{S}$ & $\mathrm{S}$ & $\mathrm{S}$ & $\mathrm{S}$ & $\mathrm{S}$ & $\mathrm{R}$ \\
\hline Quilinock & $\mathrm{S}$ & $\mathrm{S}$ & $\mathrm{S}$ & $\mathrm{S}$ & $\mathrm{S}$ & $\mathrm{R}$ & $\mathrm{S}$ & $\mathrm{S}$ & $\mathrm{S}$ & $\mathrm{S}$ & $\mathrm{S}$ \\
\hline Jindalee & S & S & $\mathrm{S}$ & S & $\mathrm{S}$ & $\mathrm{S}$ & S & S & S & S & $\mathrm{R}$ \\
\hline Mandelup & S & S & S & $\mathrm{S}$ & $\mathrm{S}$ & $\mathrm{R}$ & S & S & S & $S$ & S \\
\hline Coromup & S & S & $\mathrm{S}$ & R & $\mathrm{S}$ & $\mathrm{S}$ & $S$ & S & S & $\mathrm{R}$ & $\mathrm{R}$ \\
\hline Jenabillup & $\mathrm{S}$ & S & $\mathrm{S}$ & $\mathrm{S}$ & $\mathrm{S}$ & $\mathrm{R}$ & $S$ & $\mathrm{~S}$ & S & $\mathrm{S}$ & $\mathrm{S}$ \\
\hline Gunyidi & S & S & $\mathrm{S}$ & $\mathrm{R}$ & $\mathrm{S}$ & $\mathrm{S}$ & S & $\mathrm{S}$ & $\mathrm{S}$ & $\mathrm{R}$ & $\mathrm{R}$ \\
\hline Barlock & $\mathrm{R}$ & $\mathrm{R}$ & $\mathrm{R}$ & $\mathrm{R}$ & $\mathrm{R}$ & $\mathrm{R}$ & $\mathrm{R}$ & $\mathrm{R}$ & $\mathrm{R}$ & $\mathrm{R}$ & $\mathrm{R}$ \\
\hline $\begin{array}{l}\text { Number of "false } \\
\text { positive" }\end{array}$ & & $0^{c}$ & 0 & 6 & 0 & 17 & 1 & 0 & 0 & 4 & 8 \\
\hline
\end{tabular}

${ }^{a}$ Genotypes of R gene PhtjR on commercial cultivars: R = presence of PhtjR gene; $\mathrm{S}=$ absence of PhtjR gene [44]

${ }^{b}$ Markers showing R-allele genotype on cultivars without the $R$ gene (false positives) are highlighted in red

${ }^{c}$ Markers showing genotypes completely consistent with PhtjR gene phenotypes in all 27 commercial cultivars are diagnostic markers, and are highlighted in green

In molecular plant breeding, it is common that markers identified from DNA fingerprinting and genetic mapping may not be diagnostic even though they are closely linked to genes of interest, which limited their application for MAS in plant breeding [8-11]. In this study, we demonstrated that whole genome sequencing and re-sequencing can be applied to develop diagnostic markers for MAS through marker mining on scaffolds bearing non-diagnostic markers. All of the 24 previously-established markers linked to the 11 genes of agronomic interest in lupin were successfully located on their specific scaffolds in the genome sequence assembly. Marker mining through scaffold sequence alignments obtained, on average, 378 SNP markers and 87 InDel markers for each of 23 scaffolds bearing markers linked to lupin genes of breeder interest. In the example of PSB disease resistance, none of the three SNP

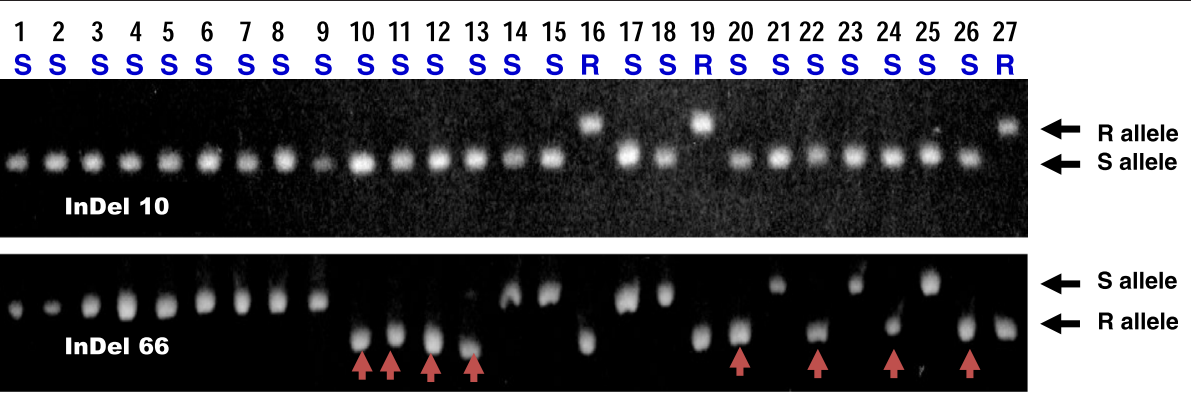

Fig. 3 Validation of InDel markers arising from marker mining on genome sequence assembly scaffold84773 linked to the R gene PhtjR conferring phomopsis stem blight disease resistance on all 27 historical and current cultivars of Lupinus angustifolius by polyacrylamide electrophoresis gels. The 27 cultivars are: Uniwhite (Lane 1), Uniharvest (Lane 2), Unicrop (Lane 3), Marri (Lane 4), Illyarrie (Lane 5), Yandee (Lane 6), Chittick (Lane 7), Danja (Lane 8), Geebung (Lane 9), Gungurru (Lane 10), Yorrel (Lane 11), Warrah (Lane 12), Merrit (Lane 13), Myallie (Lane 14), Kalya (Lane 15), Wonga (Lane 16), Belara (Lane 17), Tallerack (Lane 18), Tanjil (Lane 19), Moonah (Lane 20), Quilinock (Lane 21), Jindalee (Lane 22), Mandelup (Lane 23), Coromup (Lane 24), Jenabillup (Lane 25), Gunyidi (Lane 26) and Barlock (Lane 27). Disease phenotypes of the cultivars are presented as "S" (susceptible) or "R" (resistant) in blue letters. Marker "InDel10" was confirmed as diagnostic for the PhtjR gene, since it showed the marker genotypes consistent with PSB phenotypes on all cultivars. In comparison, marker "InDel 66" was confirmed non-diagnostic, since eight cultivars (arrowed in red) without the R gene had the resistance marker allele ("false positives") 
markers most-tightly linked (co-segregating, or $0 \mathrm{cM}$ ) to the $\mathrm{R}$ gene $P h t j R$ on the genetic map were diagnostic. These three non-diagnostic markers were located on the same scaffold87443. Of the 590 DNA markers obtained from marker mining from scaffold87443, a staggering 243 markers showed a diagnostic nature in the 10 sequenced cultivars, which illustrates the effectiveness of this marker development strategy. Three markers developed by marker mining on the scaffold (two SNPs and one InDel marker) were confirmed as truly diagnostic on all of the commercial cultivars, breeding lines and parental lines, and cosegregated with the $\mathrm{R}$ gene which is highly desirable for MAS.

Development of diagnostic markers closely linked to genes of agronomic interest is the key to the successful broad application of MAS in routine plant breeding. Functional markers, also called genic markers, are clearly the best type of marker for MAS because there is no risk of genetic recombination to cause false positives. Functional markers have broad application for MAS in a breeding program without the need for a marker validation step. In major crops, functional markers have been successfully developed and applied in plant breeding, such as functional markers for the $P m 3$ gene conferring resistance against powdery mildew disease [60], the Cre3 gene conferring nematode resistance [12] in wheat, the fragrance gene in soybean [61] and the bacterial leaf blight disease resistance genes $x a 5$ [62] and $X a 21$ [63] in rice. However, a plant genome may contain tens of thousands of genes [53, 64], and the development of functional markers requires identifying, cloning and determining the functions of target genes, all of which requires considerable research effort. The principle of the methods in developing nongenic diagnostic markers through whole genome sequencing and re-sequencing seen in this study is the same as that for DNA fingerprinting and genetic mapping in other crops, such as the SSR marker Xgwm382 for yellow rust disease resistance $[13,65]$ and a sequence-tagged microsatellite marker stem rust disease resistance gene $\operatorname{Sr} 2[66,67]$ in wheat. The marker development strategies illustrated here do not require tedious gene cloning. In MAS, markers linked to target genes within $1 \mathrm{cM}$ genetic distance provide $>99 \%$ accuracy for predicting and selecting desired genes, which satisfies the needs of most plant breeding applications. In lupin, $1 \mathrm{cM}$ genetic distance is equivalent to approximately $0.6 \mathrm{Mbp}$ in the lupin genome [38]. Such a large piece of DNA in a chromosome would cover thousands of closely-linked DNA markers, offering ample choice for identifying diagnostic markers for MAS through marker mining by genome sequencing and re-sequencing. The methods demonstrated in this study provide a solution to develop diagnostic markers for plant breeding. Further investigations such as sequencing the pathogen genome [68] and studying the plant-pathogen interactions [69] could lead to the identification of the $\mathrm{R}$ gene for the development of functional markers.

The lupin genome size is $1.1 \mathrm{~Gb}$ [38], which is slightly larger than the soybean genome at $950 \mathrm{Mbp}$ [53]. Currently, the cost of re-sequencing the whole genomes of nine lupin cultivars to a depth of 10-15 X including bioinformatics analysis is approximately US $\$ 15,000$ at the Beijing Genome Institute (BGI-Shenzhen). The cost of genome sequencing and re-sequencing in a breeding program is a one-off cost. Once the reference genome sequence and re-sequencing data are available, they can be used for genotyping and selecting diagnostic markers for any agronomic traits of interest within this species. Therefore, whole genome sequencing and re-sequencing provides a cost-effective approach for marker discovery and development for plant breeding programs. Once the marker development work is completed, it enters the marker implementation stage. Molecular markers have been applied to large-scale MAS in the Australian national lupin breeding program since 2002. Leaf samples were taken in breeder's field plots commencing from three weeks after sowing early in June when plants were in the juvenile stage. Tens of thousands of breeding plants were screened and selected with molecular markers annually [51]. The MAS work was usually completed in the end of August at flowering. The application of MAS has made a major impact on lupin breeding. For example, MAS with markers linked to anthracnose disease resistance has replaced the tedious glasshouse and field disease screening trials, which not only saved the cost, but also increased the genetic improvement efficiency in lupin breeding [51]. The development of diagnostic markers reported in this study provides lupin breeders with new tools for MAS to select phomopsis stem blight resistance in lupin breeding.

\section{Conclusions}

Genome sequencing and re-sequencing revealed large genetic variations among commercial cultivars in Lupinus angustifolius. We demonstrated two approaches for rapid development of diagnostic markers for MAS by utilizing genome sequencing and re-sequencing data: (1) by genotyping and selecting markers from genetic linkage maps closely linked to genes of breeder interest, and (2) by marker mining from scaffolds bearing non-diagnostic markers. Whole genome sequencing and re-sequencing provides an efficient and cost-effective way to develop diagnostic markers which has broad application in markerassisted selection. This approach does not require the gene identification and cloning that is needed to develop functional markers. The marker development strategies illustrated in this study may overcome the bottleneck in developing markers with wide applicability in 
molecular plant breeding. Whole genome sequencing and re-sequencing will facilitate diagnostic tests and selection without limitation of specific breeding parents or population structures. Plant breeders will be able to precisely pyramid favourable genes and alleles to develop super crop varieties to meet the future food demand.

\section{Methods}

\section{Plant materials}

Cultivars of L. angustifolius employed for genome resequencing and marker validation tests were grown from single-seed-descent derived self-pollinated lines to minimize heterogeneity. The marker population for genetic linkage analysis was the $\mathrm{F}_{8}$ RILs derived from a Unicrop (susceptible to PSB disease) $\times$ Tanjil (resistant) cross. Details on this $F_{8}$ population have been described previously [44]. Advanced breeding lines and parental lines used for marker validation were from the Australian national lupin breeding program. All plant materials are kept at the Department of Agriculture and Food Western Australia, and are available for scientific research purpose on request.

\section{Genome re-sequencing on nine cultivars}

The nine re-sequenced cultivars were Unicrop (the first fully domesticated cultivar in this species which was release in 1973), Yorrel (released in 1989), Merrit (1991), Kalya (1996), Tallerack (1997), Quilinock (1999), Mandelup (1994), Coromup (2006), and Jenabillup (2007). Resequencing of the nine cultivars was performed by the whole genome shotgun (WGS) approach [70]. DNA was extracted from three-week-old seedlings grown in a glasshouse. DNA was randomly sheared by nebulization, endrepaired with T4 DNA polymerase, and size-selected by gel electrophoresis on $1 \%$ low-melting-point agarose. A sequencing library of insert-size $500 \mathrm{bp}$ was constructed for each cultivar according to the Illumina Inc. manufacturer instructions. Pair-end sequencing of the sequencing libraries was performed on NGS platform Hiseq2000 at Beijing Genome Institutes (BGI-Shenzhen). The sequencing data for each cultivar were assembled by SOAP de novo [71]. The assembled sequences were aligned into corresponding scaffolds based on the reference draft genome sequence of Tanjil by Short Oligonucleotide Alignment Program (SOAP 2.20) [72].

\section{Marker discovery among sequenced cultivars}

Genome sequence data of the nine re-sequencing cultivars were mapped onto the reference sequences originated from cultivar Tanjil [38]. Based on the mapping result by SOAP 2.20 , uniquely mapped single-end and paired-end results were used in the SNP calling. The genotypes of each individual at every genomic site were calculated by SOAPsnp
[66]. Polymorphic loci against the reference sequence were selected and then filtered. SNP markers were recorded if they are supported by at least 3 reads with quality value greater than 20 . The InDel markers (insertions and deletions shorter than $10 \mathrm{bp}$ ) were identified by gap allowed alignment (additional parameter of "-g 10" was used in SOAP2). InDels supported by at least three pair reads were detected by SOAPindel pipeline (http://soap.genomics.org. $\mathrm{cn} /$ ) as described by Zheng et al [67]. Genomewide genetic diversity between reference cultivar Tanjil and the nine re-sequenced cultivars was based on the calculation of SNP abundance along each linkage group in the genetic map [38]. SNP numbers were counted in each non-overlapping $100 \mathrm{~kb}$ interval and displayed in a circular histogram using the software of circus (http://circos.ca/).

\section{Genotyping sequence-defined DNA markers on a genetic linkage map}

The sequence-defined lupin genetic linkage map and marker RAD sequence reads were reported previously [38]. The genome sequencing and re-sequencing data from each of the 10 sequenced cultivars were subjected to homology BLAST search with the RAD-seq sequence reads bearing the SNP markers and InDel markers from the genetic linkage map. The nucleotides from the SNP and InDel variation sites were recorded as marker genotypes for each cultivar. Marker sequences missing on the re-sequencing data were recorded as missing data. To maximize stringency, any RAD-seq sequences showing a sequence variation other than the target SNP/InDel site were discarded, and the corresponding genotype scored as "missing data". Any markers with missing data on more than three of 10 sequenced cultivars were discarded.

\section{Enrichment of molecular markers for the lupin genetic map}

The genetic linkage map of L. angustifolius contained 20 SLGs with 8,244 sequence-defined markers, in which 4,214 scaffolds from the draft genome sequence assembly were anchored [38]. DNA sequences of these 4,214 scaffolds were aligned by sequence similarity and compared between cultivars Tanjil and Unicrop, being the two parental lines for the $\mathrm{F}_{8}$ RIL population based on which map was constructed [38]. The SNP markers and InDel markers discovered from sequence alignment on each scaffold were traced to each SLG through their respective SNP markers on the map.

\section{Marker mining on scaffolds bearing markers linked to genes of agronomic traits of interest}

In the last 15 years, 24 DNA markers have been established and linked to 11 genes of agronomic traits of interest by DNA fingerprinting methodologies at the Department of 
Agriculture and Food Western Australian [14, 16, 21-30, $37,38,44]$. The marker sequences were applied to the BLAST search of the reference genome sequence [38] to identify the specific scaffold for each marker (Table 4). For each scaffold, DNA sequences from 10 sequenced cultivars were aligned to identify the SNP markers and InDel markers for each scaffold, using the principle as demonstrated in Additional file 3.

\section{Development of diagnostic markers through genotyping molecular markers from genetic linkage map flanking the R gene Phtj}

The SNP markers and InDel markers with marker genotypes on 10 sequenced cultivars (Additional file 1) flanking the R gene PhtjR at genetic distance of $5 \mathrm{cM}$ were investigated for development of diagnostic markers. The marker genotypes were compared with the $P h t j R$ gene phenotypes. A marker is considered a "candidate diagnostic marker" for PhtjR gene if its genotypes match the PhtjR gene phenotypes on all 10 sequenced cultivars. To prove the concept of selection of diagnostic markers by this strategy, five candidate diagnostic markers together with five non-diagnostic markers as controls were selected for marker validation on all 27 historical and current commercial cultivars released in Australia to confirm their diagnostic nature. Each of these 10 selected SNP markers was converted into a sequence-specific, simple PCR-based marker by designing a pair of sequence-specific primers. Screening of these converted markers was conducted by HRM using LightScanner (Idaho Technology Inc., USA) according to the manufacturer's instructions, except that EvaGreen Dye (Biotium, USA) replaced the LC Green Dye due to its lower cost and good performance.

\section{Development of diagnostic markers linked to $\mathrm{R}$ gene PhtjR through marker mining from genome sequence assembly scaffold}

The genome sequence assembly scaffold 87443 , which bears markers most-tightly linked to the $\mathrm{R}$ genes $P h t j R$ (co-segregating) on the lupin genetic map (Additional file 2) was used as a test case for marker mining to identify diagnostic markers. Genome sequencing data on scaffold87443 from 10 sequenced cultivars were aligned; all SNP markers and InDel markers from the sequence alignment were recorded (Additional file 3). Markers showing genotypes consistent with PhtjR gene phenotypes on all 10 sequenced cultivars were regarded as candidate diagnostic markers (Additional file 3). In order to validate their diagnostic nature on a broader range of cultivars, six SNP markers and four InDel markers were converted into sequence-specific PCR-based markers by designing a pair of sequence-specific primers for each. The screening of converted SNP markers was through HRM on LightScanner. InDel markers were screened on $6 \%$ acrylamide gel electrophoresis using the BIO-RAD Protean II electrophoresis unit at 80 volts for $6 \mathrm{~h}$. The 10 converted markers were tested on the 27 historical and current commercial cultivars to examine the correlation of marker genotypes and $P h t j R$ gene phenotypes.

\section{Linkage confirmation and validation of established markers}

The two diagnostic markers most closely linked to the PhtjR gene identified from genotyping markers from the lupin genetic linkage map (DAFWA6277 and DAFWA8077) and three diagnostic markers arising from marker mining from scaffold 84773 (SNP20, SNP25 and InDel10) were tested on a $\mathrm{F}_{8}$ population derived from the cross containing 186 RILs from a Unicrop (susceptible to PSB) $\times$ Tanjil (resistant) cross. The marker genotyping score data and PSB disease phenotyping data were merged and analysed using the software program MapManager QTX [45] to confirm the genetic linkage between these markers and the $\mathrm{R}$ gene PhtjR [44].

The two best SNP markers developed in this study (which were co-segregating with the R gene $P h t j R$ and diagnostic on all released commercial cultivars), SNP20 and SNP25, were further validated on the 69 advanced breeding lines and on 163 parental lines used for crossing in the Australian lupin breeding program in 2014 to evaluate their applicability for MAS in lupin breeding.

\section{Additional files}

Additional file 1: Table S1. Genotyping of sequence-defined SNP markers and InDel markers from the genetic linkage map [38] on 10 commercial cultivars through genome sequencing and re-sequencing in Lupinus angustifolius. (XLSX $475 \mathrm{~kb}$ )

Additional file 2: Table S2. Enrichment of SNP markers and InDel markers for the genetic linkage map through sequence alignment on anchored scaffolds between two parental cultivars Tanjil and Unicrop of the mapping population in Lupinus angustifolius. (XLSX $260 \mathrm{~kb}$ )

Additional file 3: Discovery of SNP markers and InDel markers, and identification of diagnostic markers for the $\mathrm{R}$ gene PhtjR conferring PSB disease resistance by marker mining on scaffold87443 in the genome sequence assembly of Lupinus angustifolius. (DOCX 171 kb)

\section{Abbreviations}

MAS: Marker-assisted selection; NGS: Next-generation sequencing; SNP: Single nucleotide polymorphism; InDel: Insertion/deletion; MFLP: Microsatellite-anchored fragment length polymorphism;

RILs: Recombinant inbred lines; PSB: Phomopsis stem blight; PCR: Polymerase chain reaction; SLG: Eequence-defined linkage group; RAD-seq: Restrictionsite associated DNA sequencing; HRM: High-resolution melting.

\section{Competing interests}

The authors declare that they have no financial and non-financial competing interests.

Authors' contributions

MWS and JC provided supervisory roles. HY and CL designed the experiments. JJ and XL performed the whole genome re-sequencing and bioinformatics. HY and DR created single-seed-descent reference cultivars and the $\mathrm{F}_{8}$ RIL plant population, phenotyped the plants, prepared the DNA 
and did the marker tests. HY, JJ, CT and CL analyzed the data and interpreted the results. HY drafted the manuscript. All authors have read and approved the final version of this manuscript.

\section{Acknowledgements}

This research was funded by the Department of Agriculture and Food Western Australia (DAFWA) through the "Lupin Marker Strategy" project, and the Grains Research and Development Corporation (GRDC) of Australia through research project "DAW00238".

\section{Author details}

${ }^{1}$ Department of Agriculture and Food Western Australia, 3 Baron-Hay Court, South Perth 6151, Australia. ${ }^{2}$ Beijing Genome Institute - Shenzhen, Beishan Industrial Zone, Yantian District, Shenzhen 518083, China. ${ }^{3}$ State Agricultural Biotechnology Centre, Murdoch University, Murdoch 6150, Australia.

\section{Received: 19 May 2015 Accepted: 24 August 2015} Published online: 02 September 2015

\section{References}

1. Beckmann JS, Soller M. Restriction fragment length polymorphisms and genetic improvement of agricultural species. Euphytica. 1986;35:111-24.

2. Gupta PK, Varshney RK, Sharma PC, Ramesh B. Molecular markers and their applications in wheat breeding. Plant Breed. 1999;118:369-90.

3. Brumlop S, Finckh MR. Applications and potentials of marker assisted selection (MAS) in plant breeding. Bundesamt für Naturschutz (BfN). 2011, Federal Agency for Nature Conservation. http://www.bfn.de/fileadmin/MDB/ documents/service/Skript_298.pdf

4. $\mathrm{Xu}$ Y, Crouch JH. Marker-assisted selection in plant breeding: From publications to practice. Crop Sci. 2008;48:391-407.

5. Collard BCY, Mackill DJ. Marker-assisted selection: an approach for precision plant breeding in the twenty-first century. Philos T Roy Soc B. 2008;363:557-72.

6. Ragimekula N, Varadarajula NN, Mallapuram SP, Gangimeni G, Reddy RK, Kondreddy HR. Marker assisted selection in disease resistance breeding. J Plant Breed Genet. 2013;1:90-109.

7. Korell M, Eschholz TW, Eckey C, Biedenkipf D, Kogel MK, Friedt W, et al, Development of a dDNA-AFLP derived CAPS marker co-segregating with the powdery mildew resistance gene Mlg in barley. Plant Breed. 2008;127:102-4

8. Sharp PJ, Johnston S, Brown G, Mclntosh RA, Pallotta M, Carter M, et al. Validation of molecular markers for wheat breeding. Aust J Agr Res. 2001;52:1357-66

9. Eagles HA, Bariana HS, Ogbonnaya FC, Rebetzke GJ, Hollamby GJ, Henry RJ, et al. Implementation of markers in Australian wheat breeding. Aust J Agr Res. 2001:52:1349-56.

10. Snape JW. Challenges of integrating conventional breeding and biotechnology: a personal view! Proceedings of the $4^{\text {th }}$ International Crop Science Congress, 26 Sep-1 Oct 2004. Brisbane, Australia (www.cropscience.org.au).

11. Holland JB. Implementation of molecular markers for quantitative traits in breeding programs - challenges and opportunities. Proceedings of the $4^{\text {th }}$ International Crop Science Congress, 26 Sep-1 Oct 2004. Brisbane, Australia (www.cropscience.org.au).

12. Ogbonnaya FC, Subrahmanyam NC, Moullet O, Majnik J, Eagles HA, Brown JS, et al. Diagnostic DNA markers for cereal cyst nematode resistance in bread wheat. Aust J Agr Res. 2001:52:1367-74

13. Akfirat FS, Ertugrul F, Hasancebi S, Aydin Y, Akan K, Mert Z, et al. Chromosomal location of genomic SSR markers associated with yellow rust resistance in Turkish bread wheat (Triticum aestivum L.). J Genet. 2013:92:233-40.

14. You M, Boersma JG, Buirchell BJ, Sweetingham MW, Siddique KHM, Yang $H$. A PCR-based molecular marker applicable for marker-assisted selection for anthracnose disease resistance in lupin breeding. Cell Mol Biol Lett. 2005; 10:123-34.

15. Ellis JG, Lagudah ES, Spielmeyer W, Dodds PN. The past, present and future of breeding rust resistant wheat. Front Plant Sci. 2014;5:641.

16. Yang H, Renshaw D, Thomas G, Buirchell B, Sweetingham MS. A strategy to develop molecular markers applicable to a wide range of crosses for marker assisted selection in plant breeding: a case study on anthracnose disease resistance in lupin (Lupinus angustifolius L.). Mol Breed. 2008;21:473-83.
17. Chia JM, Song J, Bradbury PJ, Costich D, de Leon N, Doebley J, et al. Maize HapMap 2 identifies extant variation from a genome in flux. Nat Genet. 2012:44:803-7

18. Jiao Y, Zhao H, Ren L, Song W, Zeng B, Guo J, et al. Genome-wide genetic changes during modern breeding of maize. Nat Genet. 2012;44:812-5.

19. The 3000 rice genomes project. The 3,000 rice genomes project. GigaSci. 2014;3:7.

20. Yang $H$, Sweetingham MW, Cowling WA, Smith PMC. DNA fingerprinting based on microsatellite-anchored fragment length polymorphisms, and isolation of sequence-specific PCR markers in lupin (Lupinus angustifolius L.). Mol Breed. 2001;7:203-9.

21. Yang H, Shankar M, Buirchell BJ, Sweetingham MW, Caminero C, Smith PMC. Development of molecular markers using MFLP linked to a gene conferring resistance to Diaporthe toxica in narrow-leafed lupin (Lupinus angustifolius L.). Theor Appl Genet. 2002;105:265-70.

22. Yang H, Boersma JG, You M, Buirchell BJ, Sweetingham MW. Development and implementation of a sequence-specific PCR marker linked to a gene conferring resistance to anthracnose disease in narrow-leafed lupin (Lupinus angustifolius L.). Mol Breed. 2004;14:145-51.

23. Boersma JG, Buirchell BJ, Sivasithamparam K, Yang H. Development of a PCR marker tightly linked to mollis, the gene that controls seed dormancy in Lupinus angustifolius L. Plant Breed. 2007;126:612-6.

24. Boersma JG, Buirchell BJ, Sivasithamparam K, Yang H. Development of two sequence-specific PCR markers linked to the le gene that reduces pod shattering in narrow-leafed Lupin (Lupinus angustifolius L.). Genet Mol Biol. 2007;30:623-9.

25. Boersma JG, Buirchell BJ, Sivasithamparam K, Yang H. Development of a sequence-specific marker linked to the $K u$ gene which removes the vernalization requirement in narrow-leafed lupin. Plant Breed. 2007:126:306-9.

26. Boersma JG, Nelson MN, Sivasithamparam K, Yang H. Development of sequence-specific PCR markers linked to the tardus gene that reduces pod shattering in narrow-leafed lupin (Lupinus angustifolius L.). Mol Breed. 2009;23:259-67.

27. Li X, Yan G, Renshaw D, Yang H. Development of a co-dominant DNA marker tightly linked to gene tardus conferring reduced pod shattering in narrow-leafed lupin (Lupinus angustifolius L.). Euphytica. 2010;176:49-58.

28. Li X, Yang H, Buirchell B, Yan G. Development of a DNA marker tightly linked to low-alkaloid gene iucundus in narrow-leafed lupin (Lupinus angustifolius L.). Crop Pasture Sci. 2011;62:218-24.

29. Li X, Yang H, Yan G. Development of a co-dominant DNA marker linked to the gene lentus conferring reduced pod shattering for marker-assisted selection in narrow-leafed lupin (Lupinus angustifolius) breeding. Plant Breed. 2012;131:540-4.

30. Li X, Buirchell B, Yan G, Yang H. A molecular marker linked to the mollis gene conferring soft-seediness for marker-assisted selection applicable to a wide range of crosses in lupin (Lupinus angustifolius L.) breeding. Mol Breed. 2012;29:361-70.

31. Boersma JG, Pallotta M, Li CD, Buirchell BJ, Sivasithamparam K, Yang H. Construction of a genetic linkage map using MFLP and identification of molecular markers linked to domestication genes in narrow-leafed lupin (Lupinus angustifolius L.). Cell Mol Biol Lett. 2005;10:331-44.

32. Nelson M, Phan H, Ellwood S, Moolhuijzen PM, Hane J, Williams A, et al. The first gene-based map of Lupinus angustifolius L. - location of domestication genes and conserved synteny with Medicago truncatula. Theor Appl Genet. 2006;113:225-38.

33. Nelson MN, Moolhuijzen PM, Boersma JG, Chudy M, Lesniewska K, Bellgard $M$, et al. Aligning a new reference genetic map of Lupinus angustifolius with the genome sequence of the model legume. Lotus japonicus DNA Res. 2010;17:73-83.

34. Kroc M, Koczyk G, Swiecicki W, Kilian A, Nelson MN. New evidence of ancestral polyploidy in the genistoid legume Lupinus angustifolius L. (narrow-leafed lupin). Theor Appl Genet. 2014;127:1237-49.

35. Gao LL, Hane JK, Kamphuis LG, Foley R, Shi BJ, Atkins C, et al. Development of genomic resources for the narrow-leafed lupin (Lupinus angustifolius): construction of a bacterial artificial chromosome (BAC) library and BAC-end sequencing. BMC Genomics. 2011;12:521.

36. Kamphuis LG, Hane JK, Nelson MN, Gao L, Atkins CA, Singh KB. Transcriptome sequencing of different narrow-leafed lupin tissue types provides a comprehensive uni-gene assembly and extensive gene-based molecular markers. Plant Biotechnol J. 2015;13:14-25.

37. Yang H, Tao Y, Zheng Z, Li C, Sweetingham MW, Howieson JG. Application of next-generation sequencing for rapid marker development in molecular 
plant breeding: a case study on anthracnose disease resistance in Lupinus angustifolius L. BMC Genomics. 2012;13:318.

38. Yang $H$, Tao $Y$, Zheng Z, Zhang $Q$, Zhou G, Sweetingham MW, et al. Draft genome sequence, and a sequence-defined genetic linkage map of the legume crop species Lupinus angustifolius L. PLoS ONE. 2013;8:e64799.

39. Williamson PM, Sivasithamparam K, Cowling WA. Formation of subcuticular coralloid hyphae by Phomopsis leptostromiformis upon latent infection of narrow-leafed lupin. Plant Dis. 1991;75:1023-6.

40. Van Warmelo KT, Marasas WFO, Adelaar TF, Kellerman TS, Van Rensburg IBJ, Minne JA. Experimental evidence that lupinosis of sheep is a mycotoxicosis caused by the fungus Phomopsis leptostromiformis (Kuhn) Bubak. I S Afr Vet Assoc. 1970;41:235-47.

41. Cowling WA, Hamblin J, Wood PM, Gladstones JS. Resistance to Phomopsis stem blight in Lupinus angustifolius L. Crop Sci. 1987;27:648-52.

42. Shankar M, Cowling WA, Sweetingham MW. The expression of resistance to latent stem infection by Diaporthe toxica in narrow leafed-lupin. Phytopathol. 1996;86:692-7.

43. Shankar M, Sweetingham MW, Cowling WA. Identification of alleles at two loci controlling resistance to Phomopsis stem blight in narrow-leafed lupin (Lupinus angustifolius L.). Euphytica. 2002;125:35-44.

44. Yang H, Tao Y, Zheng Z, Shao D, Li Z, Sweetingham MW, et al. Rapid development of molecular markers by next-generation sequencing linked to a gene conferring phomopsis stem blight disease resistance for marker-assisted selection in lupin (Lupinus angustifolius L.) breeding. Theor Appl Genet. 2013;126:511-22.

45. Li R, Zhu H, Ruan J, Qian W, Fang X, Shi Z, et al. De novo assembly of human genomes with massively parallel short read sequencing. Genome Res. 2010;20:265-72.

46. Yuan $H$, Yan G, Siddique KHM, Yang H. RAMP based fingerprinting and assessment of relationship among Australian narrow-leafed lupin (Lupinus angustifolius L.) cultivars. Austr J Agric Res. 2005;56:1339-46.

47. Zhao Y, Wang H, Chen W, Li Y. Genetic Structure, Linkage Disequilibrium and Association Mapping of Verticillium Wilt Resistance in Elite Cotton (Gossypium hirsutum L.) Germplasm Population. PLoS ONE. 2014;9(1):e86308. doi:10.1371/journal.pone.0086308.

48. Gowda M, Zhao Y, Wurschum T, Longin C, Miedaner T, et al. Relatedness severely impacts accuracy of marker-assisted selection for disease resistance in hybrid wheat. Heridity. 2014;112:552-61.

49. Cherukuri DP, Gupta SK, Charpe A, Koul S, Prabhu V, et al. Molecular mapping of Aegilops speltoides derived leaf rust resistance gene $L r 28$ in Wheat. Euphytica. 2005;143:19-26.

50. Manly KF, Cudmore Jr RH, Meer JM. MapManager QTX, cross-platform software for genetic mapping. Mamm Genome. 2001;12:930-22.

51. Yang H, Li C, Lam HM, Clements J, Yan G, Zhao S. Sequencing consolidates molecular markers with plant breeding practice. Theor Appl Genet. 2015;128:779-95.

52. Feuillet C, Leach JE, Rogers J, Schnable PS, Eversole K. Crop genome sequencing: lessons and rationales. Trends in Plant Science. 2011;16:77-88.

53. Schmutz J, Cannon SB, Schlueter J, Ma J, Mitros T, Nelson W, et al. Genome sequence of the palaeopolyploid soybean. Nature. 2010;463:178-83.

54. Bennetzen JL, Schmutz J, Wang H, Percifield R, Hawkins J, et al. Reference genome sequence of the model plant Setaria. Nature Biotechnol. 2012;30:555-61.

55. Plomion C, Aury JM, Amselem J, Alaeitabar T, Barbe V et al. Decoding the oak genome: public release of sequence data, assembly, annotation and publication strategies. Molecular Ecology Resources 2015 http://dx.doi.org/ 10.1111/1755-0998.12425.

56. Huang S, Li R, Zhang Z, Li L, Gu X, Fan W, et al. The genome of the cucumber, Cucumis sativus L. Nature Genetics. 2009;41:1275-81.

57. Saintenac C, Jiang D, Wang S: Akhunov E. Sequence-based mapping of polyploidy wheat genome. G3. 2013;3:1105-14

58. Huang $X$, Feng $Q$, Qian $Q$, Zhao Q, Wang L, Wang A, et al. High-throughput genotyping by whole-genome resequencing. Genome Res. 2009;19:1068-76.

59. Ariyadasa R, Mascher M, Nussbaumer T, Schulte D, Frenkel Z, Poursarebani N, et al. A sequence-ready physical map of barley anchored genetically by two million single-nucleotide polymorphisms. Plant Physiol. 2014;164:412-23.

60. Tommasini L, Yahiaoui N, Srichumpa P, Keller B. Development of functional markers specific for seven Pm3 resistance alleles and their validation in the bread wheat gene pool. Theor Appl Genet. 2006;114:165-75.

61. Juwattanasomran J, Somta P, Kaga A, Chankaew S, Shimizu T, Sorajjapinun $W$, et al. Identification of a new fragrance allele in soybean and development of its functional marker. Mol Breed. 2010;29:13-21.
62. Iyer AS, McCouch SR. Functional markers for xa5 mediated resistance in rice (Oryza sativa L.). Mol Breed. 2007;19:291-6.

63. Song WY, Pi LY, Wang GL, Gardner J, Holsten T, Ronald PC. Evolution of the rice Xa21 disease resistance gene family. Plant Cell. 1997;9:1279-287.

64. Varshney RK, Chen W, Li Y, Bharti AK, Saxena RK, Schlueter JA, et al. Draft genome sequence of pigeonpea (Cajanus cajan), an orphan legume crop of resource-poor farmers. Nature Biotechnol. 2011;30:83-9.

65. Akfirat FS, Aydin Y, Ertugrul F, Hasancebi S, Kazan K, Budak H, et al. A microsatelite marker for yellow rust resistance in wheat. Cereal Res Comm. 2010;38:203-21.

66. Roder MS, Korzun V, Wendehake $\mathrm{K}$, Plaschke J, Tixier M-H, Leroy P, et al. A microsatellite map of wheat. Genetics. 1998;149:2007-23.

67. Hayden MJ, Kuchel H, Chalmer KJ. Sequence tagged microsatellites for the Xgwm533 locus provide new diagnostic markers to select for the presence for stem rust resistance gene $\mathrm{Sr} 2$ in bread wheat (Triticum aestivum L.). Theor Appl Genet. 2004;109:1641-7.

68. Srivastava SK, Brar HK, Fakhoury A, Bluhm BH, Huang X, Bhattacharyya MK. The genome sequence of the fungal pathogen Fusarium virguliforme that causes sudden death syndrome in soybean. PLOS One. 2014;9(1):e81832.

69. Dixon RA, Paiva NL, Bhattacharyya MK. Engineering disease resistance in plants: an overview. In: Singh RP, Singh US, editors. Molecular methods in plant pathology. Boca Raton: CRC Press; 1995. p. 249-70.

70. Li RQ, Li YR, Kristiansen K, Wang J. SOAP: short oligonucleotide alignment program. Bioinformatics. 2008;24:713-4.

71. Li R, Li YR, Fang XD, Yang HM, Wang J, Lrostoamsem K, et al. SNP detection for massively parallel whole-genome resequencing. Genome Res. 2009;19:1124-32.

72. Zheng LY, Guo XS, et al. Genome-wide patterns of genetic variation in sweet and grain sorghum (Sorghum bicolor). Genome Biol. 2011;12:R114.

\section{Submit your next manuscript to BioMed Central and take full advantage of:}

- Convenient online submission

- Thorough peer review

- No space constraints or color figure charges

- Immediate publication on acceptance

- Inclusion in PubMed, CAS, Scopus and Google Scholar

- Research which is freely available for redistribution 